\title{
Climate Shifts and the Role of Nano Structured Particles in the Atmosphere
}

\author{
Bob Ursem \\ Department of Biotechnology, Faculty of Applied Sciences, Botanic Garden Delft University of Technology, \\ Delft, The Netherlands \\ Email: w.n.j.ursem@tudelft.nl
}

Received 29 October 2015; accepted 11 January 2016; published 14 January 2016

Copyright (C) 2016 by author and Scientific Research Publishing Inc.

This work is licensed under the Creative Commons Attribution International License (CC BY). http://creativecommons.org/licenses/by/4.0/

(c) (i) Open Access

\section{Abstract}

A global net sum equilibrium in heat exchange is a fact and thus a global climate change doesn't exist, but climate shifts in climate cells, especially in the northern temperate cell, do. The global climate has been ever since homeostatic, and has recuperated far huger climate impacts in the past. Current climate models need a drastically revision on the focus of carbon dioxide as main driver. Carbon dioxide and other carbon gasses do influence albedo patterns, but provide globally a homeostatic effect with a commonly accepted increase impact of 0.3 degrees Celsius. Carbon dioxide does not trigger the climate shifts, but is an indicator of exhaust of combustion processes that emit very small particles which drive these climate shifts. They are the fine dust and nano structured particles that cause the shifts of the climate in cells, as demonstrated in this article and results i.e. in more thunder and lightning, extreme weather, distinct droughts and precipitation patterns. The causes underlying these shifts are nano structured particles in the upper troposphere and lower stratosphere, especially largely produced and remain in the temperate climate northern hemisphere cell and get dispersed by jet streams and low and high pressure areas. However, because of electrical charge, caused by friction or due to anthropogenic negatively charged nano structured particle, emissions will travel up to the lower stratosphere and become neutralized at the electro sphere level, and they do also have a tendency to move to the Arctic. The southern hemisphere climate faces limited anthropogenic emissions, because only 10 percent of the world population can contribute with less pollutant providing activities, and hasn't changed, but that could well be because it is equally influenced and driven, like the northern hemisphere, by the variation of sun activity in diverse cycles. The present problem is that we produce huge amounts of air borne nano structured particles from combustion processes that never exist before. The only nano particles known in nature are those who are limited produced from volcano eruptions and natural forest fires. The natural feedback systems that moderate climate shifts and influence global climate are: convection by cumulonimbus clouds, sea currents and vegetation adaptation. A novel ultra-fine dust electric reduction device (UFDRS-System), created by the author, diminishs to a size of less than 10 nano particles in diameter and thus prevents major electrical drift of nano structured particulates in the upper troposphere and lower stratosphere and contributes largely in purifying the air and thus reduces the effects of climate shifts. 
Like solving the acid rain problems with sulphuric acid reduction and ozone depletion with CFCs proscription in the past, the present climate shifts can be mitigated via a reduction of the anthropogenic nano structured particulates in the atmosphere. The UFDRS-System together with the given nature's solutions can re-balance our atmosphere in a period of two years or a little bit longer due to extension of the lifespan of a particle in the stratosphere.

\section{Keywords}

Nano Structured Particles, Electricity, Climate Shifts

\section{Introduction}

The scientific consensus on climate change is that it is mainly driven by carbon dioxide due to emissions and use of fossil fuel [1]. In this article, I will show that carbon dioxide is not the driver, but a (useful) indicator of fossil burning and production processes that create nano sized particles (and particulate matter) which do affect climate shifts via coagulation and nucleation.

Before I will elaborate on the thesis that nano particles are the main cause of climate shifts, we will discuss the contemporary consensus that we have global climate-change with an expectation that we will face at least 3 degrees Celsius overall warming caused by increases in the amount of carbon dioxide in the atmosphere and, show that in some respect, the reasoning about global change can be improved. If you consider the impact of carbon dioxide as the main driver, how to explain that the troposphere can have a global impact on climate change while it only contains $5 \%$ carbon dioxide and the other $95 \%$ consists of water (water vapour and water droplets). A global impact is numerically very doubtful, because the main absorption components are water vapour and water droplets (Figure 1). Carbon dioxide and other carbon gasses do influence albedo patterns, but provide globally a homeostatic effect with less impact increase of 0.3 degrees Celsius. The IPCC [1] so far puts forward that water vapour (in total to the whole atmosphere 4\%) is a "feedback" of the greenhouse effect and maintains in all models carbon dioxide as the final cause (in total to the whole atmosphere $0.038 \%$ ). Furthermore, air at higher altitudes gets colder with an average decrease of 0.6 degrees Celsius per 100 meter as a result of adiabatic cooling. Water will become ice in the higher troposphere levels changing its physical properties, while carbon dioxide does not freeze and at this level the main gas absorbs infra-red radiation back into space, thereby warming the atmosphere on the spot in contrast to a total global heating process. Furthermore, gasses like $\mathrm{CO}_{2}$ are known not to have a mass that can absorb heat and keep it, while water as a liquid or as ice in a solid state has thermal capacity. Gasses do have a natural homogenous diffusion pattern, while nanoparticles, because of a mass, do not. However, because of cell circulation patterns nanoparticles remain and affect processes in a particular climate belt with very limited exchange between climate belts.

Another aspect to global climate change as presented by the IPCC should lead to increasing global heating processes that eventually unbalance the atmosphere. This disregards many other feed-back systems that naturally do occur on our globe. IPCC deals with a huge network of interesting physical science basis components (Figure 2), and even mentioned aerosols as a minor component in climate change processes, but says nothing about nano sized structures and electrical forces, nor do they see Maunder patterns as generic driver. I see carbon dioxide only as a very important indicator of different anthropogenic processes in climate shifts. Furthermore, IPCC disrespect the fact that the net sum of downwardly directed long-wave radiation resulting in a global warming process is totally in balance with the upwardly directed long-wave radiation from earth into space [2].

I put forward that climate change is actually a climate shift and not a global phenomenon of an increased heating process. However, the impact can be disastrous on a regional scale and especially on the Northern Hemisphere and next global variation with local climate differences follow of course natural patterns correlated to the sun activity.

I hypothesize that the main driver for this climate shift can be found in the lower stratosphere and the explanation will focus on condensation and nucleation of nano sized structures. First of all, because only convection processes shift the heat distribution driven by initially Maunder patterns, then cloud formation (special reference 


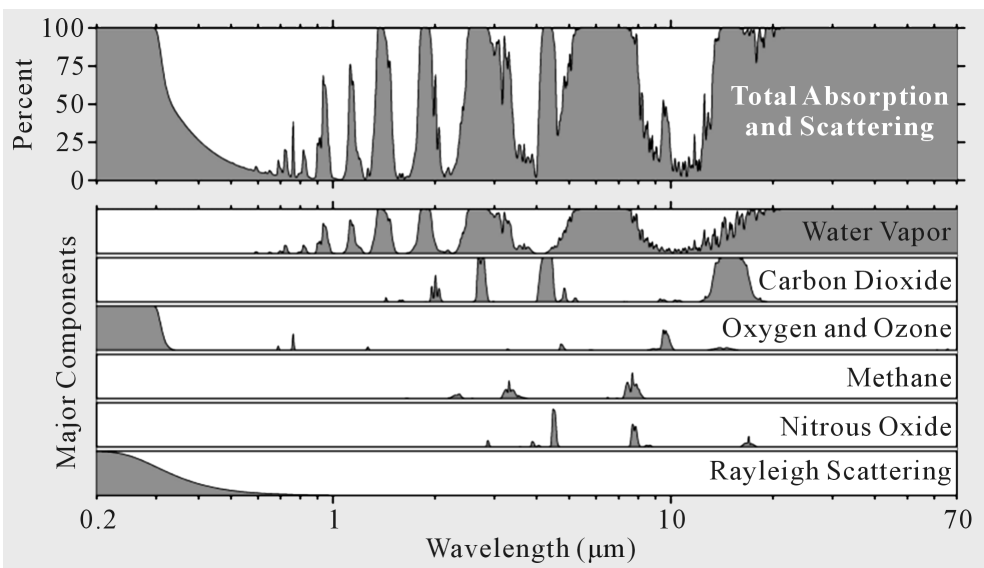

Figure 1. Source: Image created by Robert A. Rhode/Global Warming Art, Berkeley 2011.

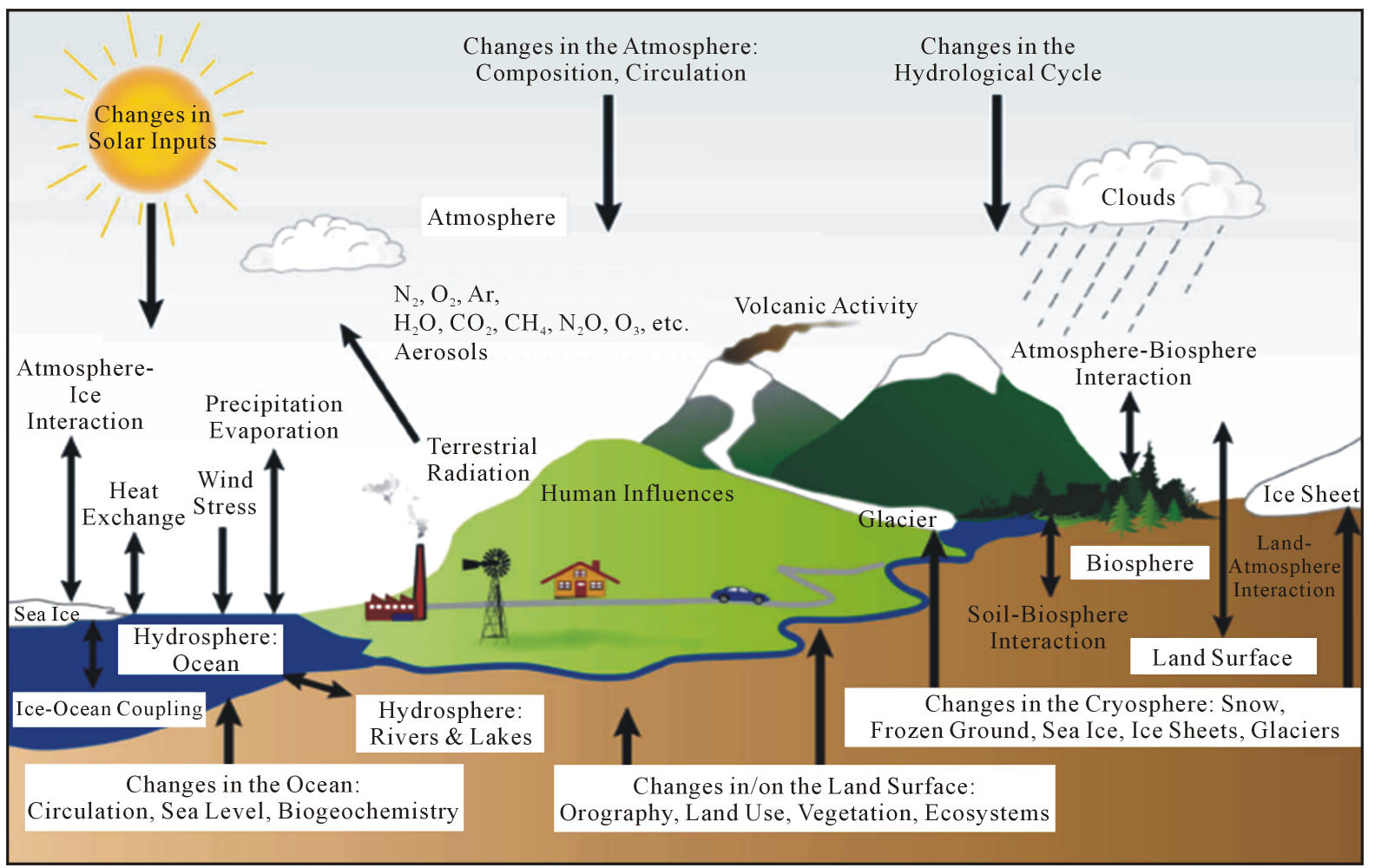

Figure 2. Source: IPPC, Climate Change 2007, the physical science basis.

to cumulus and cumulonimbus) caused by distribution patterns (global atmospheric cells and Coreolis force driven jet-streams), which interact with sea-currents, water and land (special reference to vegetation), and last but not least the anthropogenic influences that provides increasing weather extremes.

Particles of particulate matter of anthropogenic origin do occur in the stratosphere, while the general assumption is that the boundary layer of pollution extends to a height of $3 \mathrm{~km}$, and more extreme at the top of a convective boundary layer at a height of $5 \mathrm{~km}$ above deserts in mid-summer or 50 meters at night under fair skies and no wind or maximum light wind conditions [3]. Empirical research has shown however, that many nano sized particles also can be found in the stratosphere [4] and most of them are in the range of only a few tenths of nanometre in diameter, like nano sheets in clay minerals, nano rods in nano fibrous minerals, like the discovered cristobalite nano fibres $\left(\mathrm{B}-\mathrm{SiO}_{2}\right)$ in air fall deposits during the eruption of Chaitén Volcano in Patagonia (Chile) [2]. The third dimension of nano range particles besides nano sheets and nano rods is formed by anthropogenic and 
natural nanoparticles. The natural nanoparticles can be produced during eruptive modes, including lava flows, pyroclastic flows, and lahars, as nano-sized minerals or mineral condensed gas nanoparticles. These natural events contribute to air borne mineral dust at a rate of 1600 megatons per year of which a contribution of 165 megatons per year is made of air borne particulate matter of 1 micrometre or less in size [5]. Besides natural production of nano-particles, anthropogenic Nano-particulates formed by combustion processes will play an increasingly important role in climate models as we will discuss in this study.

To what height do nano structured particles reach in the stratosphere? Most of the known aerosol nano particles in the stratosphere, found between approximately $17 \mathrm{~km}$ till $50 \mathrm{~km}$ altitude, are of large volcanic eruptions and major meteorite impacts and they are known to have global impacts for months or years and in these periods even altering earth climate shifts.

The stratosphere as a whole is known to contain little water vapour. Cloud formation can only occur at the tip of the boundary layer at extreme polluted conditions or during winter at the polar regions at temperatures below $78^{\circ} \mathrm{C}$ as Polar Stratospheric Clouds or PSC's at an altitude of 15 till $25 \mathrm{~km}$. Next to little water vapour (20\% water vapour and cloud droplets content) is the evidence of bacteria in the stratosphere, detected at an altitude of $41 \mathrm{~km}$. The existence of very small bacteria in the size of nano-bacteria has been recognized in the stratosphere [6] and these findings were based on the evidence of bacteria-like structures in an Allan Hills meteorite found by David McKay in 1984 [7]. However, sub-micron cocci-like bacteria in the order of 1 micrometre in diameter and cocci-like structures as fimbriae of a size of 300 nanometre are detected with a balloon-transported cryosampler [3] [8]. An another remarkable sample of the upper stratosphere has been detected at an altitude of 25 km by Bigg [9], who sampled thin, rod-shaped bacteria-like particles of approximately 500 nanometres in diameter with a transmission electron microscopy. Bigg provides also evidence of the existence of double membranes, which occur (comm) only in bacteria on earth. Alsomany other publications provide evidence of bacteria life in the stratosphere [6] [10] [11].

Not only bacteria, water vapour and diverse forms of nanoparticles can reach the stratosphere from earth, also atmospheric gases, carbon dioxide, nitrogen oxide, multiple molecules and even a number of aerosol particles. Humanity contributes for instance via aviation and other forms of mobility or via combustion processes. A straight pollutant factor is aircrafts injecting gas exhaust particles directly into the troposphere and stratosphere. The gas exhaust combustion engine is also characterised by a $50 \%$ positive and $50 \%$ negative charged particles [12] and an aircraft produces more nano structured particles than an automotive combustion system. Jet aircraft combustion engine exhaust yielded nuclei mode of less than 10 nanometres, 10 till 30 nanometres up to nanoparticles up to 100 nanometre in diameter with a mass emission factors spanning from 0.02 to 0.2 grams per kilo burned fuel or in CPC measurements $3-50 \times 10^{15}$ particles per kilo burned fuel [13]. And more recent higher elemental carbon over organic carbon ratios in aircraft gas exhaust combustion particles have been reported by [4] [14]. Although we know that there are way particles in the troposphere it is of importance for mitigation strategies to know how they get there and what effects they engender in relation to climate shifts.

\section{How Do All These Nano Structured Particles Pass the Boundary Layer?}

It is known that volcanic eruptions can eject particles beyond the tropopause straight into the stratosphere. However, volcanic eruptions are subjected to sedimentation because of gravity and will only disrupt the stratosphere in deposit for a limited period of time. It is generally known that the tropopause or boundary layer act as a barrier to the upward movement of any kind of particles, except for volatiles and gasses. All particulate matter can also pass the boundary layer in a conical blue jet during blue lightning strikes from the top of a thundercloud with a speed up to hundred thousand metres per second into the stratosphere [15] or been carried and speed up in huge plumes of smoke during forest fires and lightning at the same time. An another pathway can be provided by refraction and reflection of photons on particulate matter and increase the kinetic energy at the sun radiate side and induces via electromagnetic energy a temperature difference within the particle resulting in a photophoretic force opposite to gravity [5] [16]-[18]. However, as stated earlier, emission of a gas exhaust combustion engine is characterised by $50 \%$ positive and $50 \%$ negative charged particles [12]. Automotive gas exhaust combustion engines provide a yield between 0.1 till 1 micrometre particle diameter. Nano scale fractions in the smaller diameter range, like polycyclic aromatic hydrocarbon and other components with a positive charge will coincide with gravity and directed to the earth surface (earth is grounded) and negative charged ones will lift 
against gravity and be driven by electric force. Negative charged combustion nano structured particles tend to move upwards, following the direction of the electric field lines between grounded earth surface and the positive charged atmosphere. The negative charged particles can both be intercepted and neutralized, or, due to friction, become more negatively charged and lift upwards towards the boundary layer and interact with solar radiation. The solar interaction on particles and nano particles is especially seen at the tip of the boundary layer.

It is found that solar radiation may heat at the tip of the boundary layer in excess of $4^{\circ} \mathrm{C}$ per hour in the case of a strongly polluted boundary layer with combustion produced particles, measured with a zenith angle of $45^{\circ}$ and a corresponding infrared cooling rate op to $0,25^{\circ} \mathrm{C}$ per hour at normally pass rates. The global radiation at the earth's surface is decreased by a strong pollution, while the infrared downward radiation is significantly increased at the same time [19]. This is induced by aerosols, atmospheric gases, water vapour, carbon dioxide and nitrogen oxide and in addition to multiple molecules and aerosol particles, especially nano structured particles. Which of the mentioned components do interact well with solar radiation? Water absorbsat all bands of water vapour and forms a composite of intervals with the sun's radiation, of course with the assumption that only aerosol particles, air molecules and water vapour interacts with each other [19]. The other interaction with the solar energy is $\mathrm{NO}_{2}$, air molecules and aerosol particles. Air molecules and aerosol particles also interact with the remainder of the solar spectrum.

There is a huge difference in humidity and the possible nucleation on nano structured collide aerosols at the tip of the boundary layer in the lower stratosphere. In fair sky conditions, without any cloud formation at the tip of the boundary layer in the lower stratosphere, solar radiation heating rates show strong maxima, even exceeding $4^{\circ} \mathrm{C}$ per hour at high humidity rates and heavily polluted inversion layer at the tip till $2^{\circ} \mathrm{C}$ per hour in conditions of low humidity and with strongly polluted tip of the inversion layer, all measured at a solar zenith angle of $45^{\circ}$ and according to the spherical harmonics method described by Zdunkowski and Korb [20] and by the emissivity method of Rodgers [21] to include overlap effects.

Next to a blue jet, a huge smoke plume and lightning, or a photophoretic force, can anthropogenic nano sized particles be driven by pure electrical forces as a result of gas exhaust combustion engines injected by subsonic and supersonic aircrafts (in ratio 3\% contribution to global carbon-dioxide production) or as non-intercepted negative charged or neutral charged residue of other origin (burning processes in ratio of energy plants 25\%, households $23 \%$, industry $19 \%$, traffic $12 \%$ and shipping $1 \%$ of the global carbon-dioxide production) [22].

As been stated, evidence of nano structured particles above the altitude of the boundary layer has been detected for nano sheets, nano rods, nano fibres, bacteria and anthropogenic components. Lifting forces on the nano structured particles can be jets, in particular blue jets, huge smoke plumes and due to lightning. The drivers are a photophoretic force based on electromagnetics or negative charged electricity, directly as such released or due to friction, of a non-intercepted nano structured particle of anthropogenic origin. All uplifting forces will drag negative and neutral nano structured particles onto the stratopause at approximately $50 \mathrm{~km}$ altitude, where all get neutralized as described hereafter and accumulate.

The stratopause is well defined by its distinct temperature gradient of approximately $0^{\circ} \mathrm{C}$ till a maximum of $10^{\circ} \mathrm{C}$ (see Figure 3). The stratopause is also the zone where solar proton events (SPE's) do occur. A bombarding of highly energetic protons causes ionizations, excitations, dissociations, and dissociative ionizations of the background constituents, like $\mathrm{HO}(\mathrm{x})$ production and $\mathrm{NO}(\mathrm{y})$ products out of $\mathrm{N}_{2}$ at the boundary zone or stratopause between the stratosphere and mesosphere [23]. Higher energy protons loose energy in creating ion pairs (HO and NO) because of electron removal (i.e. a secondary electron) from a neutral molecule or atom due to a precipitating high energy proton, leaving behind a positive ion and charging the stratopause positive! The protons impart energy on the secondary electrons cause's further ionizations in the atmosphere and so contributing to the charges at the stratopause.

Next to this phenomenon at the stratopause is the effect of solar wind, releasing charged particles, mostly electrons and protons, from the upper atmosphere of the sun at a corona discharge and all these bombards on the earth atmosphere. The earth is protected by its magnetic field which deflects most of the charged particles or trapped them in the Van Allen radiation belt in the high atmosphere. The protons are trapped and the electrons will slip through to impact on the earth surface, especially at the poles. Because of the electron impact on earth, the earth is negative charged or grounded. On the other hand, the atmosphere is positive charged and results in an increase of electric field per meter altitude between the earth and sky. This field is at the ground of course zero and builds up with 90 - 120 Volts per meter, depending on climatological and atmospheric conditions, up to the inversion (boundary) layer in the troposphere, that ranges roughly between 300 up to 3000 meter altitude in 


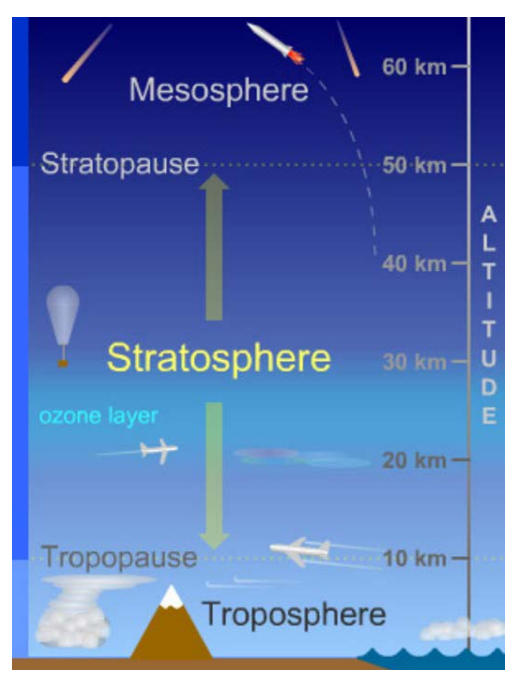

Figure 3. Source: windows of the universe by Randy Russell, 2012.

regard to climatological local conditions [24]. Because of interception of 'relative' large particles and less nano structured particles at the inversion layer, nano structured particles face a decline of the electric field per meter while getting at higher altitude levels in compare to lower troposphere. Nano structured particles move further on an increase of electric force to a value of approximately 5 Volts per meter above the inversion layer [25]. Because of low pressure-already at $5500 \mathrm{~m}$ altitude $50 \%$ (approximately $\mathrm{p}=500 \mathrm{mb}$ or $\mathrm{p}=500 \mathrm{hPa}$ ) of the ground pressure (approximately $\mathrm{p}=1 \mathrm{mb}$ or $\mathrm{p}=1 \mathrm{hPa}$ ) —and because of the less dense particle content the value increase of 5 Volts $/ \mathrm{m}$ remains nearly unchanged up till the stratopause at approximately $50 \mathrm{~km}$ altitude.

Nearly all electrical negative charged nano structured particles will continue to uplift above the inversion layer into the stratosphere. At the stratopause the electric field will be calculated approximately 600.000 Volts static electric field. In the lower stratosphere range of $17 \mathrm{~km}$ till $30 \mathrm{~km}$, the static electric field build up will be ranging from approximately 430.000 till 495.000 Volts, assuming the conditions of $120 \mathrm{Volt} / \mathrm{m}$ increase up till 3000 meters inversion layer and 5 Volt per meter increase above this limit. This static electric field build up forms obviously a great driver on the movement of negative charged nano structured particles towards the stratopause.

These nano structured particles collide and will get electrical neutral charged by the intercepted protons in stratopause or will coagulate and nucleate at lower stratosphere levels.

Nano sizes particles can also coagulate and nucleate in the lower stratosphere and form with the existing water vapour ( $20 \%$ of the stratosphere consists of water vapour) small water nucleation pockets, mostly in ice because of the temperature. Whereas at higher altitudes near the stratopause they melt to or remain till small water droplets, because the temperature at that level ranges from zero to ten degrees Celsius (see Figure 4). It is most plausible however that nucleation of nano structured particles will occur in the lower stratosphere in proportion to higher levels of the stratosphere, because the water content declines as well with altitude. Next, the nucleation time itself could only be enlarged because of the existing static electric field, but has no effect on the final nucleation process [26]. The water vapour content in the lower stratosphere is a result of radiation of earth atmosphere, absorption of short wave solar radiation and convection of heat transport. The studies of Miskolszi [2] [27] with radiosondes show clearly that the net global radiation sum never changed and that the downwardly directed long-wave radiation is totally and since earth atmosphere existence in balance with the upwardly directed longwave radiation (see Figure 5).

The regulatory mechanism that keeps the global atmosphere in balance is convection, so including air bubbles rises and uptakes of water vapour from the sea and land (mainly vegetation) into the atmosphere. The up take is strongly related to temperature, water vapour (i.e. water temperature or transpiration of plants) and vapour pressure. This results in the largest cloud formations in the tropics, mainly cumulus and cumulonimbus clouds. The latter can easily range well above both the inversion layer and the tropopause, and as a result ends up to $13 \mathrm{~km}$ till $17 \mathrm{~km}$ altitude to inject water vapour directly into the lower stratosphere. 


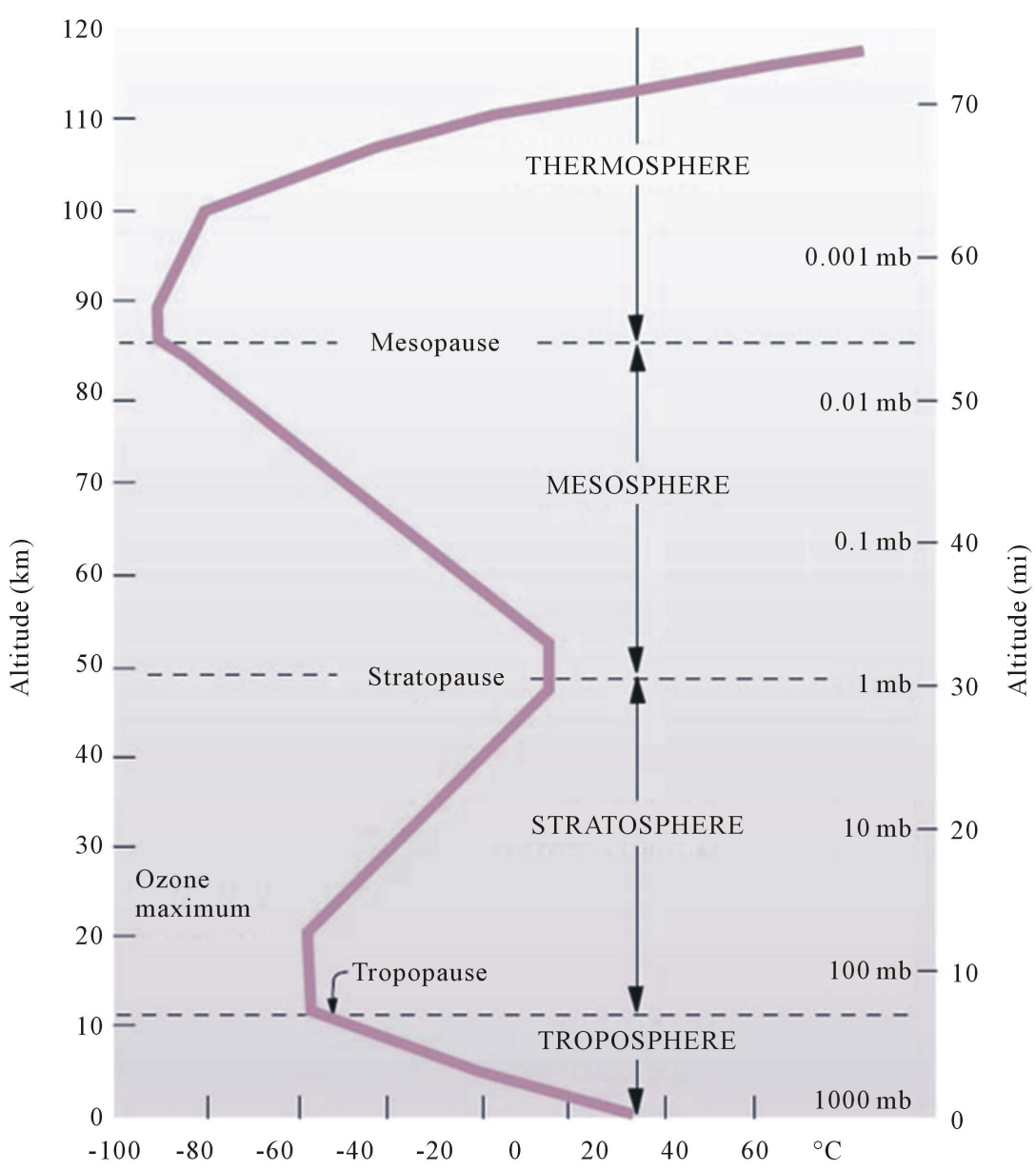

Figure 4. Source: C. Donald Ahrens, essentials in meteorology.

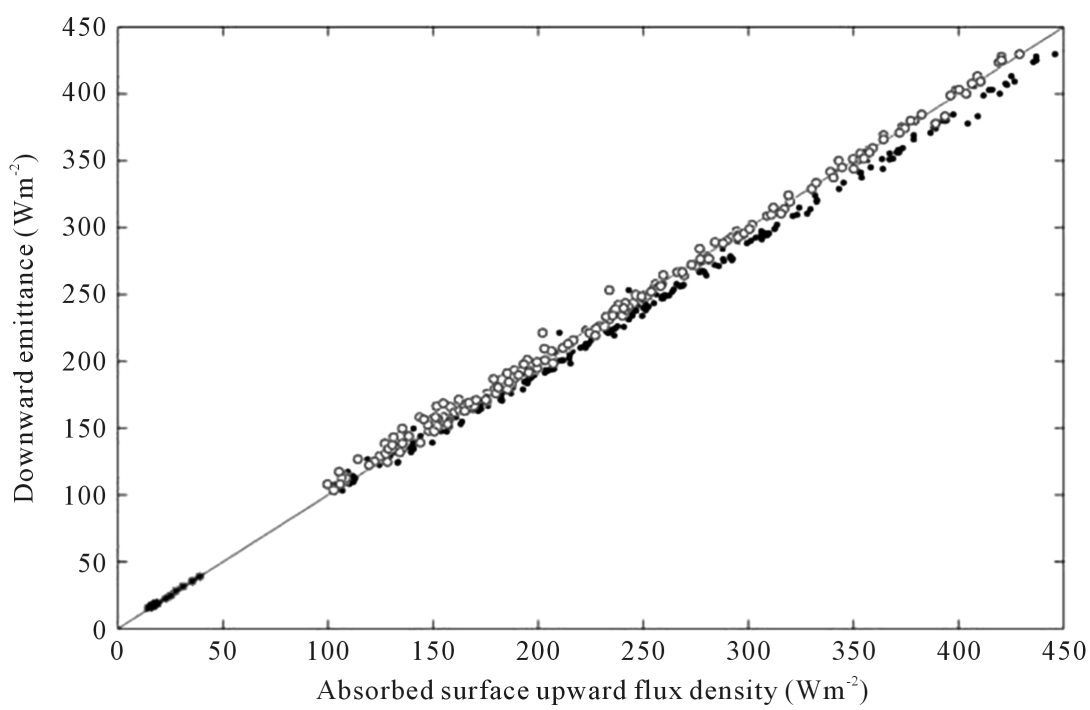

Figure 5. 228 selected radiosondes in graph depicting on the vertical axis the downwardly directed long-wave radiation and on the horizontal axis the upwardly directed long-wave radiation. The earth is not warming in a holistic point of view Source: E. Miskolszi (2008). 


\section{What Is the Impact of Coagulation and Nucleation of Nano Sized Particles on Cloud Formation in the Lower Stratosphere and Convection?}

Clouds can bring water vapour into the higher troposphere and lower stratosphere due to uptake of water vapour, mainly from ocean, sea, and on land, i.e. a lake or a river as evaporation and as transpiration of vegetation. Open water evaporates less than vegetation transpiration. Vegetation contributes to the water vapour, because of its roughness, leaf surface area or LAR (Leaf Area Ratio) and LAI (Leaf Area Index). In particular trees transpire much more in compare to grassland, bushes and crops. Wind, linear to transpiration, plays an important role in the moisture distribution and up take of water vapour due to advection, but on the other hand the capacity declines in vegetation, because hanging water in plants can more easily be shed of leaves. Trees contribute in forests till about $50 \%$ of the precipitation in a hydrological cycle [28]. This is a significant amount in the recirculation of water from forests to cloud formations, especially in the tropics. Tropical vegetation has nearly all its biomass above the soil and the largest roughness of all vegetation types in the world, so therefore the contribution to evaporation is also the highest amount. In combination with high temperatures is the cloud formation in the tropics nearly always cumulus or cumulonimbus clouds that could reach up to $13 \mathrm{~km}$ or $17 \mathrm{~km}$ altitude, depending on convection, temperature and wind.

The geomorphology, especially mountains, can contribute in an increase of water vapour into the stratosphere and at the other hand can water vapour more easily form droplets in the troposphere due to adiabatic cooling along a slope and repeatedly nourishes locally the hydrological cycle. Cloud formation occurs when water vapour and nuclei coagulates to form water droplets during its up take and affection by adiabatic cooling in altitude.

All natural particles of earth origin are neutral or negatively charged; the latter because the earth is grounded. There for all rooted vegetation, nearly all plants except epiphytes, produces negative charged particles and negative charged nano structured particles into the air. Next to temperature driven forces can negative charged particles contributes to an uplifting effect or even accelerate this process (i.e. thunderstorms or forest fires). Such acceleration process starts with cloud formation. First cumulus clouds come into existence and the tops shoot up, while beneath an increasing moisture addition takes place. The cumulus clouds builds up and transform into a cumulonimbus cloud, because the droplets at tip of the clouds reaches the threshold and becomes ice. A selfsustaining process will evolve, because upward winds engine water vapour upwards and pushes dry air at the outside downwards, which will get moisture below and rotate upwards again and all this results in a thunderstorm. Inside the clouds uplift water will vapour and negative or neutral particles coagulates in an increasing violent force because of the speeding upwardly rotator. Due to this process, the wind speed inside a cumulonimbus cloud can easily ranges from $10 \mathrm{~m} / \mathrm{s}$ up to $50 \mathrm{~m} / \mathrm{s}$. At such turbulence, due to friction, negative charging and the knocking off of electrons of nucleated droplets, charges the lower part of the cloud negative as well. The positive remnant droplets will be strongly lifted, due to electrical forces and sucking effects of upper ice formation and arrive as positive charged ice particles at the tip of the cloud into the lower stratosphere. It only needs ionized air to bridge the conductivity and lightning evolves. There is a strong correlation between the amount of ice crystals in the upper cloud tip and the number of lightning events, regardless if it is above water or land [29]. Furthermore, the formation and sucking effect of a cumulonimbus cloud speeds up the evaporation as well, which cools the air (evaporation cost energy) and there for lower the air temperature at ground level during the thunderstorm. As a result, a thunderstorm remains longer active and performs locally a wonderful cooling system to climate shifts.

Evaporation and transpiration are not only just processes of water vapour and wind, but also vapours pressure. When vapour pressure equals the saturation vapour pressure, evaporation from water equals also the condensation and form droplets that uplift by sun radiation heating processes. Nucleation takes spontaneously place via homogenous nucleation at a saturation ratio that exceeds 3.5 at $20^{\circ} \mathrm{C}$ and at 4.5 at zero degrees Celsius [30].

In other situations are negative charged and neutral charged nano structured particles co-existing together with water vapour in the lower stratosphere. Recent studies show that the condensational growth rate various greatly among nano sized particles in the atmosphere and thus also in the stratosphere, because it is related to the size and charges [31].

Yli-Juuti et al. measured median growth rates of particles in the nucleation mode sizes in diameter 1.5 - 3 nanometres, 3 - $7 \mathrm{~nm}, 7$ - $20 \mathrm{~nm}$ that grew to respectively $1.9 \mathrm{~nm} \cdot \mathrm{h}^{-1}, 3.8 \mathrm{~nm} \cdot \mathrm{h}^{-1}$ and $4.3 \mathrm{~nm} \cdot \mathrm{h}^{-1}$, these figures with an uncertainty factor due to size distribution instrumentation that ranges of $25 \%, 19 \%$, and $8 \%$ respec- 
tively. The nucleation of 1.5 - $3 \mathrm{~nm}$ diameter and the positive particles, in comparison to negative charged nano particles, yielded on average a higher growth rate, while particles larger than $3 \mathrm{~nm}$ show no systematic differences [31]. Furthermore, growth rates of 7 - $20 \mathrm{~nm}$ diameter particles showed in their study a positive correlation in nucleation growth with mono-terpene components of pine trees. The growth rate could be related on one hand to the oxidation rate by ozone and at the other hand to a limitation due to concentrations of organic precursors. In the lower stratosphere nucleation processes could occur parallel to these findings and interact with possible other gas components to contribute to a nucleation process in the same manner and form droplets. These droplets cause the visible haze effects in the lower stratosphere, which can be seen in the northern temperate cell and the Arctic. Nowadays, Arctic visible haze has almost become permanent, because of anthropogenic pollution.

\section{How Stratospheric and Tropospheric Clouds Do Regulate the Climate Shift at a Global Scale?}

Because the clouds are cooling it has an effect on the climate shifts and especially in the case of a cumulonimbus. Most of the cumulonimbus clouds are formed in the tropics, where we have the largest sun radiation impact and the highest cloud-formations on earth. The distribution of clouds around the globe is subjected to low and high pressure areas and the jet streams. Earth circulations are the best expressed in climate cells, such as in the tropics the Hadley cells, in the temperate regions the northern and a southern temperate cell and at the poles an Artic cell and an Antarctic cell.

At the equator air rises and takes up moisture and forms cumulus clouds and often also cumulonimbus clouds and both results in a cool rain in the tropics that provides a stable average day temperature that ranges from $30^{\circ} \mathrm{C}$ up to $35^{\circ}$ Celsius and at night between $20^{\circ} \mathrm{C}$ and 25 Celsius. Because of this very steady situation, the downward wind results in a dry tropical wind, clearly shown in Figure 6 at the tropic of Cancer on the northern he- misphere and the tropic of Capricorn at the southern hemisphere. Because of the downward dry winds at both tropics it consequently gives an outcome in rarely any cloud formation. This downward wind at both tropics triggers at both hemispheres also a downward and little more moisture wind from the temperate cells that effect in very limited precipitation, and in most cases as fog (i.e. Namib desert in Africa or Atacama desert in South America).

The temperate cell at the northern hemisphere, which ranges up to the Arctic circle, is more variable and dominated by regional low and high pressure areas, depending on the variations of sun radiation (daily- and seasonal cycles), its position on land or ocean and the geomorphology. Next to all these mentioned factors exits the influence of the jet streams. The temperate zone at the southern hemisphere is very similar to the hereby given description of low and high pressure areas and jet stream effects and others as described for the northern hemisphere, except that the southern hemisphere is dominated by oceans in a land and ocean ratio of 1:4, while the northern hemisphere is dominated by landmass in a ratio of land to ocean area is 1:1.5. This results in the southern temperate cell in a clear distinct and more moderate, predictable distribution patterns of precipitation, of turbulent winds and die down areas. Climate domination by ocean differs greatly from the northern temperate cell. The northern temperate cell is characterized by very turbulent and changing systems of low and high pressure areas in diverse regions of land, ocean and mixed surfaces. At the edges of both temperate cells, entering the Arctic in the north and Antarctic in the south, there is downward predomination of wind, bringing in cold rain, snow and ice, as depicted in Figure 6. This triggers and drives at both sides of the globe the climate in the polar cells.

Each polar cell acts as a system on their own, and there is a big difference between the Arctic and Antarctic. The Arctic is dominated by ocean, while the Antarctic is dominated by landmass. Water and atmosphere at the Arctic is generally cold, so there is a limited exchange capacity, except in the summer. As a result, the average precipitation is low in the Arctic. The main input of precipitation will be around the zone in the vicinity of the Arctic Circle. The Arctic net sum of snow precipitation is not accumulation, but depletion and melting glaciers.

At the Antarctic the polar climate cell is in principle similar to the Arctic polar cell, cold air circulates with a limited exchange and produces a small amount of precipitation and most of it as snow. Like the Arctic, the cloud formation and precipitation has to come from the surrounding ocean and is in average $166 \mathrm{~mm}$ per year. In contrast to the Arctic however, shows the Antarctic a net average yearly increase in accumulation of snow [32]. Evidence for this accumulation is also given by Knuth (2007) [33]. Knuth's data ranges between $1.5 \mathrm{~mm}$ per year 


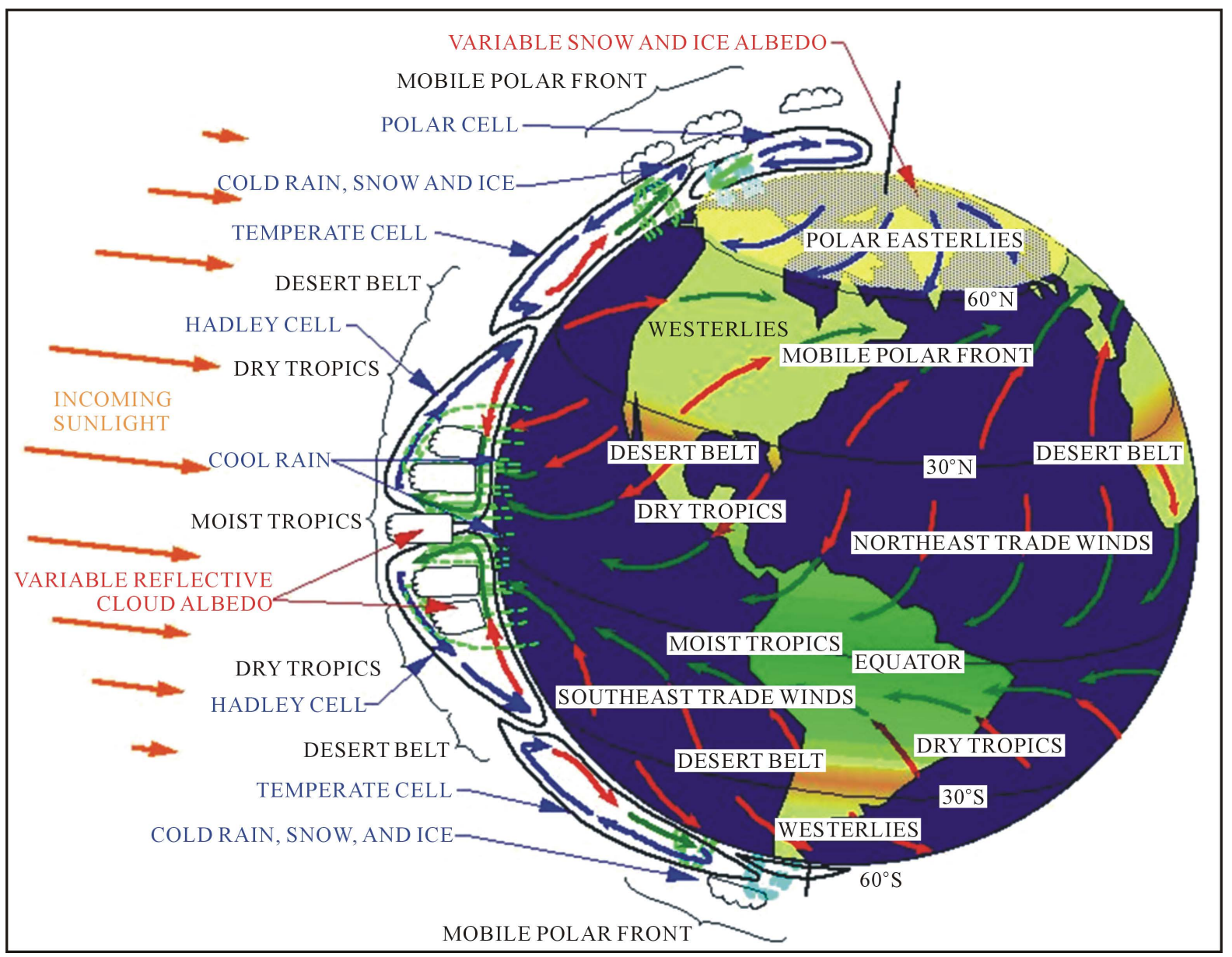

Figure 6. Source: Willis Eschenbach, http://www.oarval.org (2009).

up till 50 mm per year over the period between 2004-2006. Knuth took even distinct photographs of stratified snow deposits (see Figure 7). Furthermore, the satellite image (Figure 8) of Davis et al. [34] shows a distinct glacier thickening in eastern Antarctica, a near balanced precipitation and ice loss in north-eastern area and a thinning in the Amundsen and Bellingshausen Sea in the west.

Finally, Antarctica is dominated by a very strong and small circumpolar jet stream, resulting in strong winds and frequent gales, consequently also a very turbulent circumpolar sea. Two additional factors that divide the Antarctic climate cell exchange to the more temperate southern cell.

\section{To What Extend Differ the Southern Hemisphere and the Northern Hemisphere in Relation to Climate Shift?}

There are numerous data available of the northern hemisphere, which is in contrast to the southern hemisphere and to begin with Antarctica, where data are measured since 1957. Since measurements taken, it shows no correlation between the temperature readings of the Antarctic and Arctic [35]. Antarctica shows already a huge difference in snow accumulation from the Arctic [29].

Evidence is also given by Jones et al. [36] that evidently proofs over the period of 1851 till 1984 that there is no correlation to be given between the temperature readings in the temperate southern hemisphere and the northern hemisphere. If we include the data obtained since 1957 of Antarctica in addition, we see one overall trend of long term warming of $0.5^{\circ} \mathrm{C}$ over the past century and a period of cooling between 1938 till 1965 .

This cooling period (1938 and 1965) is very much in coherence with the solar activity proxies of Usoskin et al. [37]. Usoskin et al. measured the 10 Beryllium-isotope from the sun, which has a half time of 26 million years, and connected these results to a robust correlation reconstruction of data on the 11-year solar cycle average. 


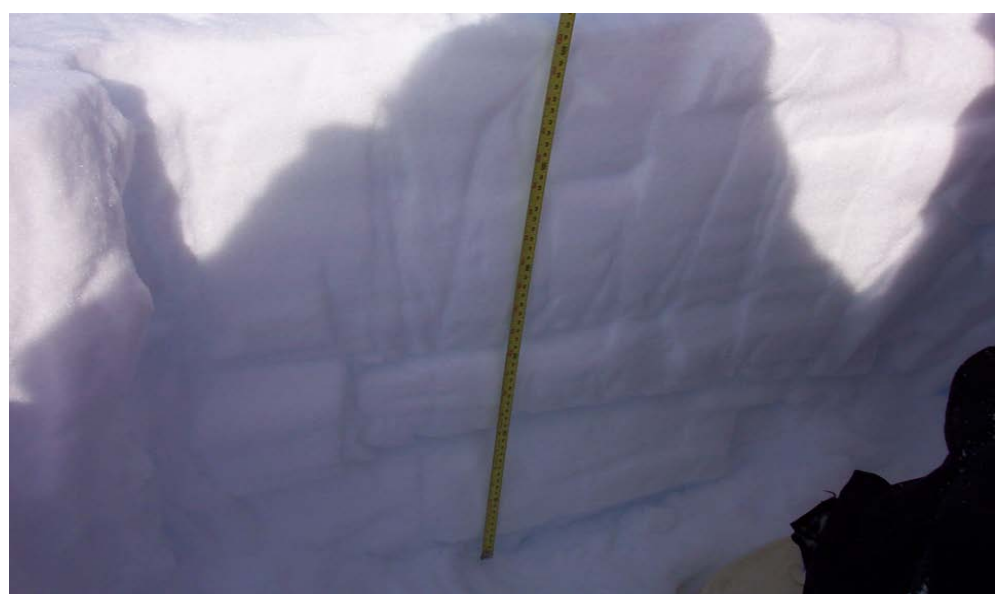

Figure 7. Source: Knuth, image of horizontal accumulation from a snow pit as taken at Ferrell site on the Ross Ice Shelf in January, 2006.

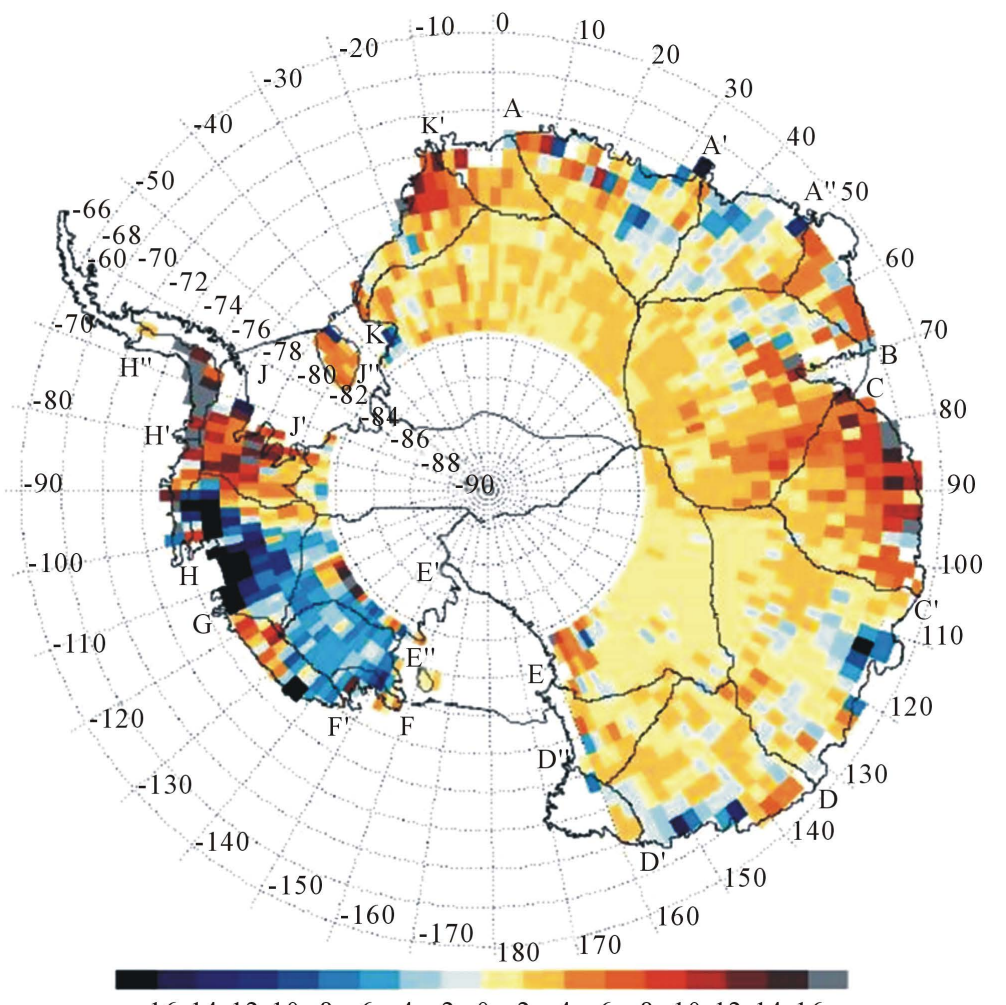

$\begin{array}{lllllllllllllll}-16-14-12-10 & -8 & -6 & -4 & -2 & 0 & 2 & 4 & 6 & 8 & 10 & 12 & 14 & 16\end{array}$

Figure 8. Source: Davis et al., 2005.

Evidence was fixed in ice cores in Greenland and resulted in reconstructed annual data set for the period of 1424 till 1985 on sunspot numbers (Figure 9). Usoskin et al. took also the 10 Beryllium-isotope and 14 Carbon-isotope measurements from ice cores of Antarctica and reconstructed the period sunspot events between 850 till 1900 and could perfectly match those data with the Greenland findings (Figure 10).

There are no recent climate measurement data available of the southern hemisphere before 1858 [38]. But Hansen et al. show a cool period between 1880 till 1900 in the southern latitude $\left(23.6^{\circ}-90^{\circ} \mathrm{S}\right)$ and a strong warming in the late 1960s, and both are clearly in line with the solar activity proxies (Figure 9). So we may conclude that the sun is the main driver of the global climate.

However, there is a recognized distinct difference within this greater sun activity related driver between the 
northern and the southern hemisphere. Before we will elaborate further on the thesis of solar radiation effects on Arctic and Antarctica in relation to global climate effects in climate belts, we will focus on the differences in glaciation on both hemispheres.

Evidence for a net accumulation of glaciation on Antarctica is in line with the findings on glaciers in New Zealand. Purdi [39] gives evidence of a net accumulation of snow on the Franz Josef glacier and the Tasman Glacier in New Zealand. Purdi associates the snow accumulation to the Southern Oscillation Index (SOI) and Southern Annual Mode (SAM) variability to the mid-latitude jet stream. The mid-latitude jet stream can be positive, providing an overall low pressure area above Antarctica and a high pressure area above New Zealand. This results in New Zealand's Southern Alps a positive SOI and SAM giving increased eastern and northern winds and a decreased snow accumulation, while a negative jet stream provides dominant westerly and southern winds and a distinct snow accumulation.

Separated of Purdi's findings on the Franz Josef glacier, we see other parallels to stratosphere effects. The snow accumulation on Franz Josef glacier, as depicted in Figure 11, show a remarkable parallel trend with the water vapour component in the lower stratosphere since 1980 till 2008 by Solomon [40], as depicted in Figure 12. Stratospheric water vapour in the Solomon's graph show a drastic decline between 2000 till 2001 that could result in a direct decline of snow fall in conjunction with an hasten after effect in snow accumulation on the Franz Josef glacier. The record variations in the length of the Franz Josef Glacier show also a dip in the midnineties, but that could be related to the southern jet change in the atmosphere.

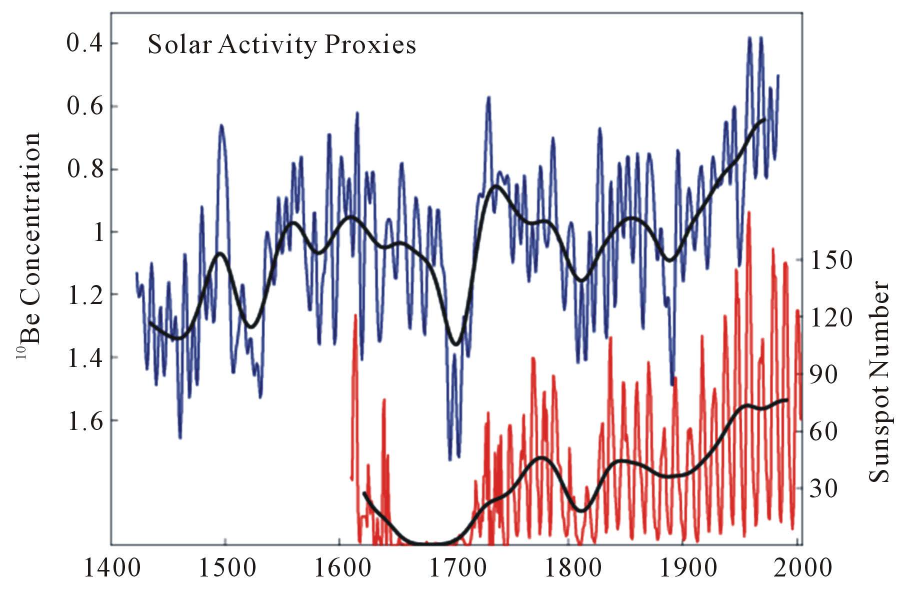

Figure 9. Source: http://www.klimaatgek.nl, 2013.

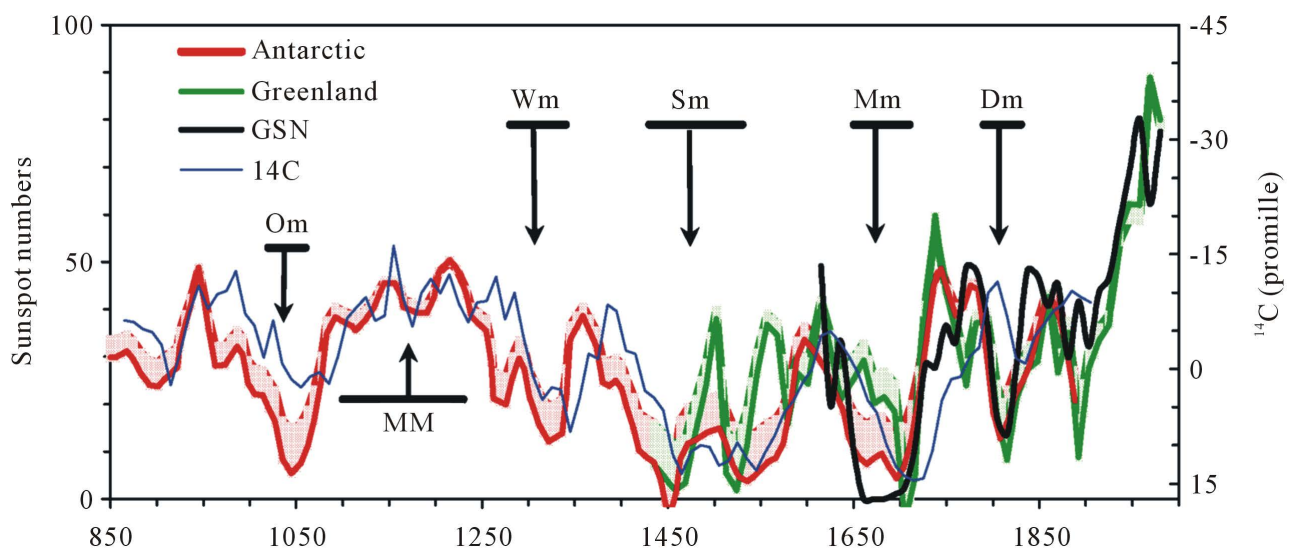

Figure 10. Source: Usoskin et al. 2003; Legend: ${ }^{10}$ Be-isotope concentrations in ice core from Antarctica (red) and Greenland (green). GSN (Group Sunspot Number) indication great minima and maxima: Oort minimum (Om), Medieval maximum (MM), Wolf minimum (Wm), Spŏrer minimum $(\mathrm{Sm})$, Maunder minimum (Mm), Dalton minimum (Dm). ${ }^{14} \mathrm{C}$-isotope concentrations in tree rings, corrected for the variation of the geomagnetic field. 


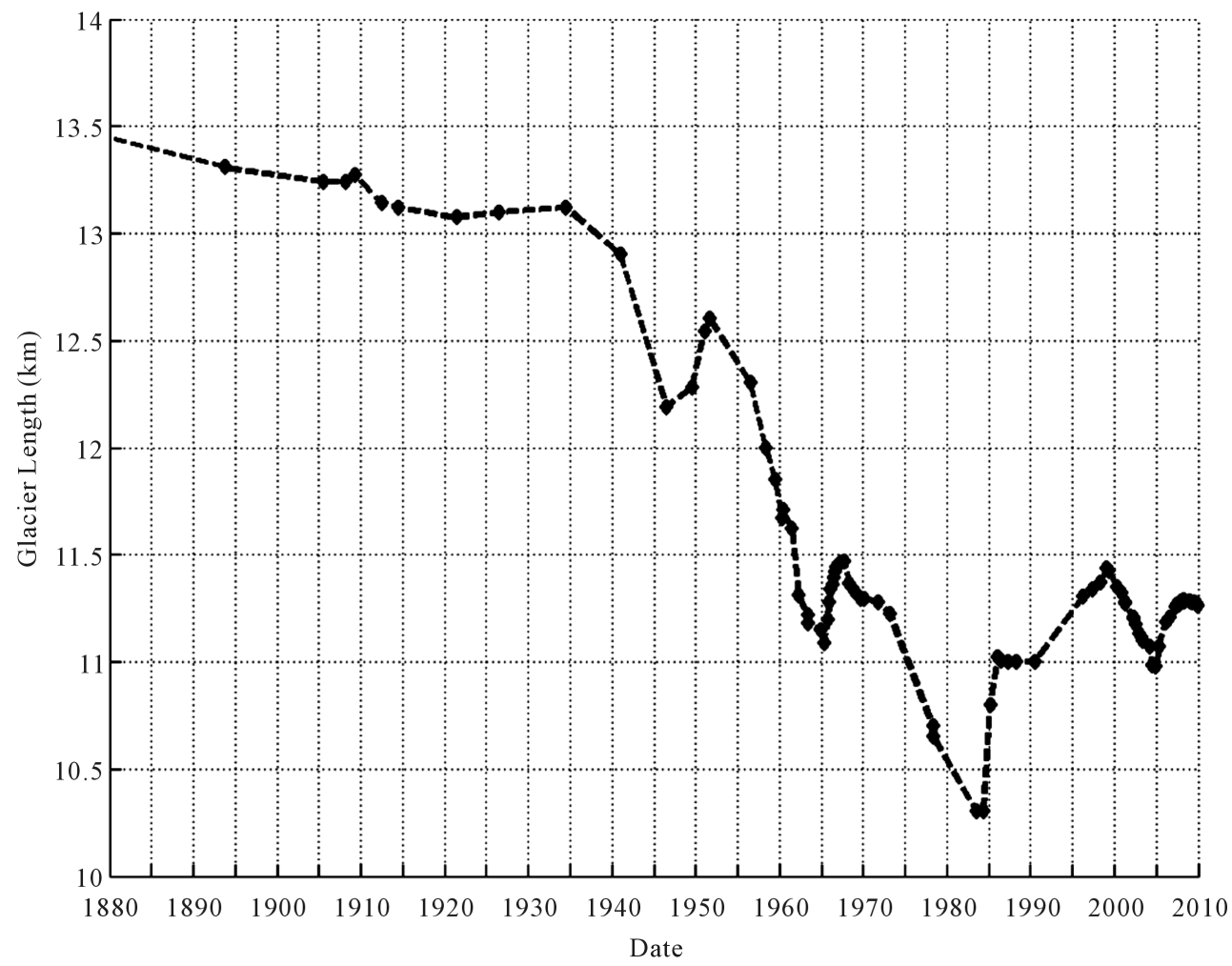

Figure 11. Source: http://www.geo.unizh.ch/wgms, Glacier Monitor Report 2009/2010, Recorded variations in length of the (Ka Roimata 0 Hine Hukatere), Franz Josef Glacier, New Zealand, from 1880 to present.

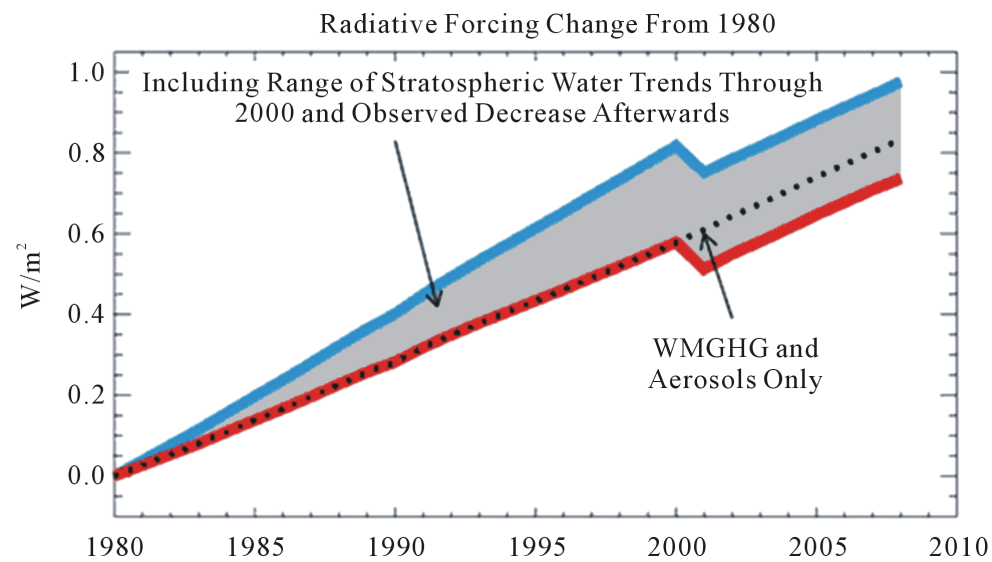

Figure 12. Source: Solomon, 2010, impact of changes in stratospheric water vapour on radiation forcing since 1980 due to well-mixed greenhouse gases (WMGHG), aerosols, and stratospheric water vapour. The shaded region shows the stratospheric water contribution.

The glaciation situation in South America is very different to Antarctica and New Zealand. The Northern Patagonian Ice field(NPI) in Chile and the Southern Patagonian Ice field(SPI) at the border of Chile and Argentina, that covers respectively 4200 and $13.000 \mathrm{~km}^{2}$, melt both rapidly with figures for NPI of $2.63( \pm 0.4) \mathrm{km}^{3}$ annually and for SPI $7.2( \pm 0.5) \mathrm{km}^{3}$ per year [41]. The annual precipitation is 2 till 11 meter per year, but because the steep east-west gradient it results in an increasing washes off effect of ice (and water).

The most feasible correlation between this huge and relative very warm precipitation can be found in the 
change of the jet stream along the coast of Chile due to the change of solar flares activity [42]. De Jager stated: "During the emission of solar flames, and more specific with X-Ray and UV radiation, associated energetic particles-effects influencing the ionosphere (radiation), will fill the high-latitude of the upper atmosphere (stratosphere) with particles. However, nano structured particles will be also affected with electrical charges of cosmic rays and will coalesced with the existing water vapour to cloud droplets, because cloud droplets condensate on the nuclei of nano sized aerosol particles". Furthermore De Jager stated that solar activity as described in an 11-year solar cycle or an 80-year solar cycle or as well as any other period, also effects changes in the jet stream through magnetic effect caused also by particles. De Jager's findings were substantiated by Svensmark and Christensen [43], who observed variation of $3 \%-4 \%$ of the global cloud cover during the recent solar cycle and could strongly correlate this with cosmic ray flux and inversely with the solar activity. The jet stream along Chile is a typical characteristic negative jet and north-south directed, bringing in extreme humid warm air from the tropics. This assumption is according the findings of Batten et al. [44] that an equatorial surface current and a poleward undercurrent, both as part of the Peru Humboldt coastal upwelling system, generate meanders, filaments and eddies in response to a predominant equator ward wind forcing or an almost constant north-south directed warm and very humid wind resulting in more rainfall in higher altitudes than snow. This results in the net glacier depletion in the Andes of South America.

There are only two Andean exceptions to be noted. First the Pio XI glacier in Chile, which is the largest glacier in South America, $1263 \mathrm{~km}^{2}$, and the longest outside Antarctica, $65.7 \mathrm{~km}$ length, that is characterized by a net accumulation of $44.1 \mathrm{~m}$ thickness with an increase volume of $2.52 \mathrm{~km}^{3}$ between 1945 till 1995, which can be calculated to an average snow height addition of $2.2 \mathrm{~m}$ per year [45]. The second is the Perito Moreno glacier in Argentina, covering $257.3 \mathrm{~km}$ and with a total length of $30 \mathrm{~km}$, which is still accumulating $5250 \pm 660 \mathrm{~kg} \cdot \mathrm{m}^{-2}$ per year [46]. Although no report is given on the origin of both glacier growing phenomenons, it is clear that both glaciers are obvious well protected in a relative narrow gorge or surrounded by extreme high mountains and less exposed as other glaciers in South America. Furthermore Pio XI and Perito Moreno glaciers are both he only less perpendicular in the Andean mountain range to the predominant jet stream of warm humid air [47]. An another additional factor that can be found is the fact that both glaciers are positioned at a very south latitude and that predominant northern jet stream driven warm humid winds are cooled before due to adiabatic processes. As a result providing cold drifts to high altitudes and more snow precipitation on the Pio Xi and Perito Moreno glaciers.

The only remnant and non-discussed other glacier on the southern hemisphere is Mount Kilimanjaro in Tanzania. The glacier on Mount Kilimanjaro was completely covered by a single uninterrupted ice cap during the Little Ice Age (1550-1850) and diminishes after. Research on ice cores, taken from the North Ice Field glacier, gave insight that the ice deposit was at least 11,700 years old [42]. Up till 1953 the annual ice loss was still 1\%, and increases since 1989 to a factor of 2.5\% [48]. The main reason for the ice loss is related to depletion of lowland and montane rainforest and secondary growth clearings, so loss of interception [49] and 50\% loss to the recirculation of the hydrological cycle [28]. At Mount Kilimanjaro occurs also a very sensitive response to a microclimate shift of an increasing drought as a result of a generic jet pattern change for total eastern Africa, and so recently speeding up the process of glacier depletion [50].

On all discussed continents of the southern hemisphere is snow accumulation registered, except for Africa, mainly due to vegetation loss and decreasing precipitation, and for South America, due to a feasible predominance of a northern humid warm jet stream. These findings are very much in line with the data obtained from the National Climate Data Centre 2013 (Figure 13).

However, the northern hemisphere shows a very different picture that gives evidence of extreme differences in compare to the average on the rest of the globe's atmosphere (Figure 13). The tropical zone shows very limited variations from the average temperature in both Hadley Cells. Considering the temperature data from 1981 till 2010 (Figure 13), it is very unlikely to keep the idea of an equal global warming, but more that the southern hemisphere and the northern hemisphere turn out to give an independent climate response. It is naturally also very unlikely that energy exchange between the southern hemisphere and the northern hemisphere will occur in the atmosphere, because energy needs to be transferred by particles or fluid materials. If it was triggered by a gas, such as carbon dioxide or any other, diffusion will be according to the gas laws and should have resulted in a global overall effect. Consequently, according to the thought that carbon dioxide is driver to climate effects, it results otherwise in a non-separated global climate picture and this is very much in contrast to the temperature readings of the National Climate Data Centre (Figure 13) and completely perpendicular to the hard evidence of 


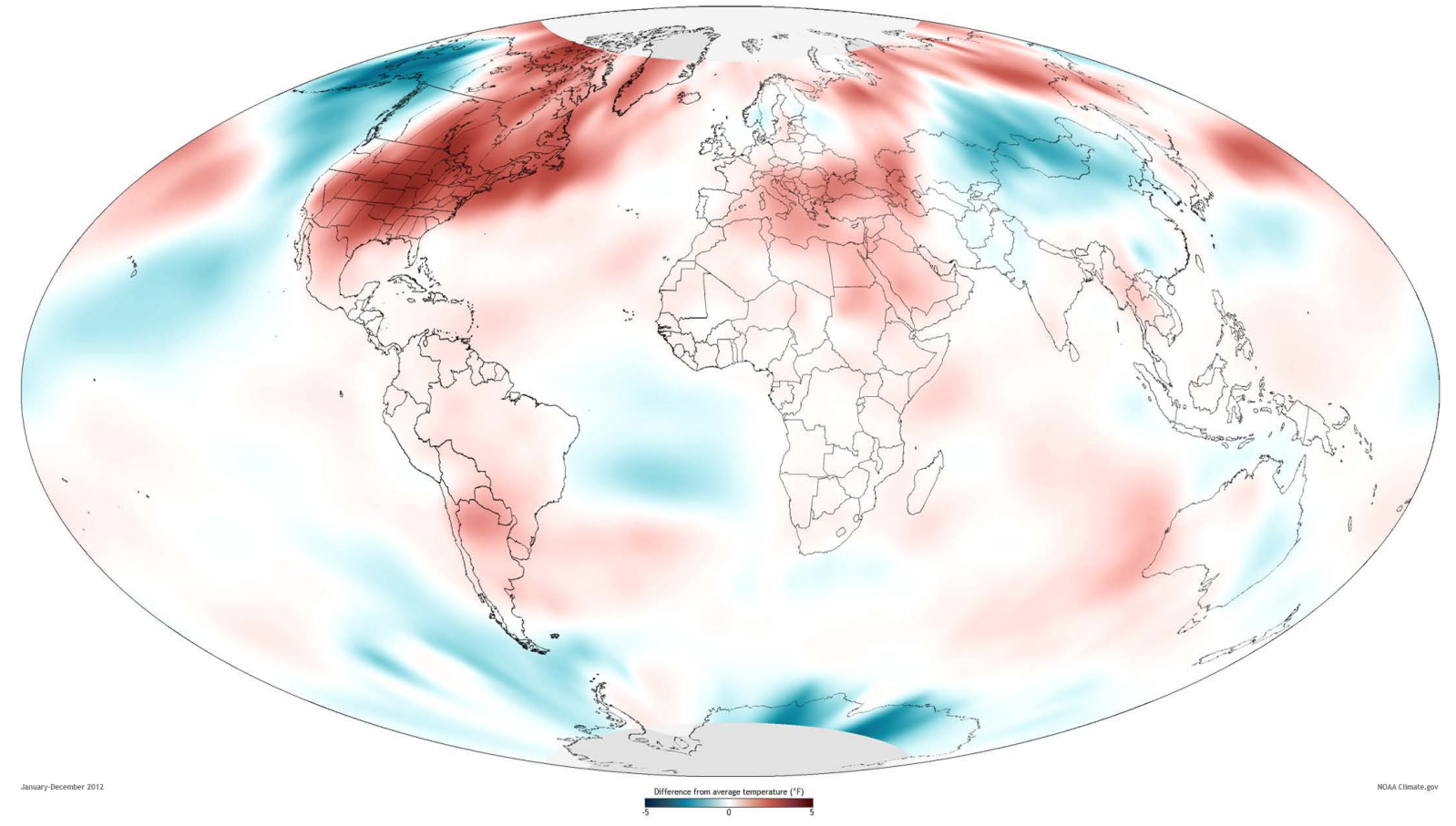

Figure 13. Source: national climatic data centre: Surface temperatures in 2012 compared to the 1981-2010 average. NOAA map by Dan Pisut, NOAA environmental visualization lab, based on merged land and ocean surface temperature data.

[2] as depicted in Figure 5. A global climate change or increase in temperature doesn't exist; it is rather more a climate shift in one or more cells. Another evidence can be found in the solar cycle of 8400 years ago, that shows the same hockey stick graph as presented for the present climate change by the IPCC [51]. Next is the evidence of carbon dioxide in the relation and the existence of stomata, and the geo-carbon bonding on earth, and that evidently shows approximately 100 million years ago a high stomata existence in leaves at a 20 times more carbon dioxide rate in the atmosphere as present [51]. We still face the same atmosphere today and evidently completely recuperated this phenomenal carbon dioxide emission of the past. Plants regulate the carbon dioxide in the atmosphere as given in the increase of stomata in the past, but also in vegetation adaptation, for example in a tundra to enhance the fixation of carbon dioxide [52]. At the moment, it is obvious that the temperate northern hemisphere cell shows the largest and most extreme atmospheric variation on the globe. How can the temperate northern hemisphere cell turn into such extremes? The answer can be found in nano structured particles due to anthropogenic pollution.

\section{Nano Structured Particles as Possible Main Driver of the Climate Shift in the Temperate Northern Hemisphere Cell and Affecting the Arctic Cell}

The temperate northern cell is dominated by landmass (land-ocean ratio is $1: 1.5$ ) where $90 \%$ of the world population lives. This is in huge contrast to the southern hemisphere, where the land-ocean ratio is 1:4 and only provides homes to the other $10 \%$ of the world population. Consequently nearly all anthropogenic emissions of atmospheric aerosols from industry, traffic, housing and energy production are produced on the northern hemisphere in the temperate climate cell, effecting and polluting the environment.

It is obvious that air crafts do inject directly in our upper troposphere and stratosphere, although their factual contribution is very limited in the stratosphere resulting in a figure of about $1 \%$ [30], because most planes fly just in the upper troposphere, except the supersonic ones. Emission that reach the stratosphere are nano structured particles of combustion that trespasses the inversion layer, such as sulphuric acid droplets of industry that accumulates at 18 - $20 \mathrm{~km}$ altitude in the Junge layer, named after Christian Junge, who discovered microscopic aerosol particles while searching cosmic dust and debris of nuclear bomb tests and water vapour.

The major aerosol anthropogenic particle production is of the automotive mobility, heating houses, industry 
and energy production. Cars do provide emissions of air borne particles between 100 nanometres and 1 micrometre in diameter, except for diesel that can aggregate to a number of tenths micrometres in diameter. But, due to the introduction of a catalytic converter, the emission of particles increases four times in number and become much smaller. As a result, nearly all the exhaust emissions of cars is in the range of nano structured particles, in numbers the diameter size less than 50 nanometres and in mass the size in diameter between $50 \mathrm{~nm}$ up to less than a $1000 \mathrm{~nm}$ [53]. Most of these nano structured particles are hydrocarbons or sulphate and get nucleated during dilution and cooling of the gas exhaust. These little larger particles in the accumulation mode are predominant carbonaceous soot agglomerates and are directly produced by combustion.

In addition, nano structured particles are 50\% negative charged [12] and provide an electrical uplift, so will get straight into the troposphere affecting the climate shift. This is very much in contrast to the larger particles, which have a tendency to remain turbulent at lower levels as everyone can observe when a car, truck or bus drives away in wintertime with a strong visible condensation on the emitted particles.

Particles of heating houses are characterized by its combustion materials, like coal that provides exhaust of 70 up to 75 nanometres in diameter, while wood produces ranges of 10 till 20 nanometres and 40 till 50 nanometres average, and in a limited amount up to $63 \mathrm{~nm}$ in size [54]. All these and like other combustion processes are 50\% negatively charged and follow the same pathway as air borne automotive combustion exhaust as described earlier.

Industry is very similar to households, except they don't use predominant wood firing, but gas and coal, and they are nowadays equipped by an electrostatic precipitator in their exhaust pipe to reduce particulate matter and sulphur dioxide.

These electrostatic precipitators seem to be very friendly to the environment and the climate effects, but this is not true. There are two commonly used systems, electrostatic precipitators (ESP) and wet electrostatic precipitators (WESP). In ESP systems are negatively electrical charged plates with high voltage placed in the exhaust and all combustion gasses are forced by an accelerator that speed up all exhaust components along these plates while charging. Next is a grounded receptor plate opposite positioned to catch particles while passing. The WESP systems uses a similar construction with an additional saturated air stream $(\mathrm{RH}=100 \%)$ to wash out sulphur dioxide, converting this into sulphur acid that flushes down and get removed. The problem with electrostatic precipitators (ESP) and wet electrostatic precipitators (WESP) is the exhaust gas-speed through this filter system. Nano structured particles, like chemicals for example referring to coal as arsenic, selenium, sodium, sulphur and other pollutants, passes at a far too high speed along the ESP and WESP filters and there for will be injected negatively charged straight into the troposphere. Nano structured particles need a longer pathway in such a filter system in order to get a deposition at the grounded receptor plates. In ESP and WESP filters are only the larger particles of nearly micrometre sized and greater in diameter, captured. This results in a release of nano structured particles and shows lacking of condensation processes, so no show off of a visible smoke plume.

Energy production in power stations, especially in those which are driven by fossil fuel combustion, provides equivalent gas exhaust as industry and are normally filtered with ESP or WESP systems. nano structured particles do pass the boundary layer, reach the upper troposphere and get into the stratosphere, as explained in this article.

On top of this pollution of negative charged nano structured particles provides in the air also an increase to the electrification of the atmosphere. In 2005, Williams give indeed evidence of an increase of electrification in drier areas of the United States, resulting in $26 \%$ increase of strong violent storms. In a warmer climate in the temperate northern hemisphere cell, we can expect perhaps more thunderstorms and lightning because of temperature differences between lower troposphere level and the higher stratosphere level, due to vapour input at high altitudes and formation of ice on nano structured particles and warming up at lower troposphere altitudes. However, when a cumulonimbus cloud is pushed higher into the stratosphere, the lower troposphere will get drier and reduces the formation of thunderstorms [55]. The natural drier areas show a higher frequency of thunderstorms and lightning, as depicted in Figure 14, except for humid tropical regions. In humid tropical regions, there is a higher uplift tendency of cumulonimbus clouds in the stratosphere [56] resulting in less frequency, but longer thunderstorm lasting, and effective cooling of the climate. Recent studies of Seeley and Romps in 2015 [57] show already an overall increase of lightning in the United States by 12 percent at an atmospheric temperature increase of just one degree Celcius. Seeley and Romps stated their records on calculations and lightning observations with an accuracy of 77 percent prediction and outcome. 


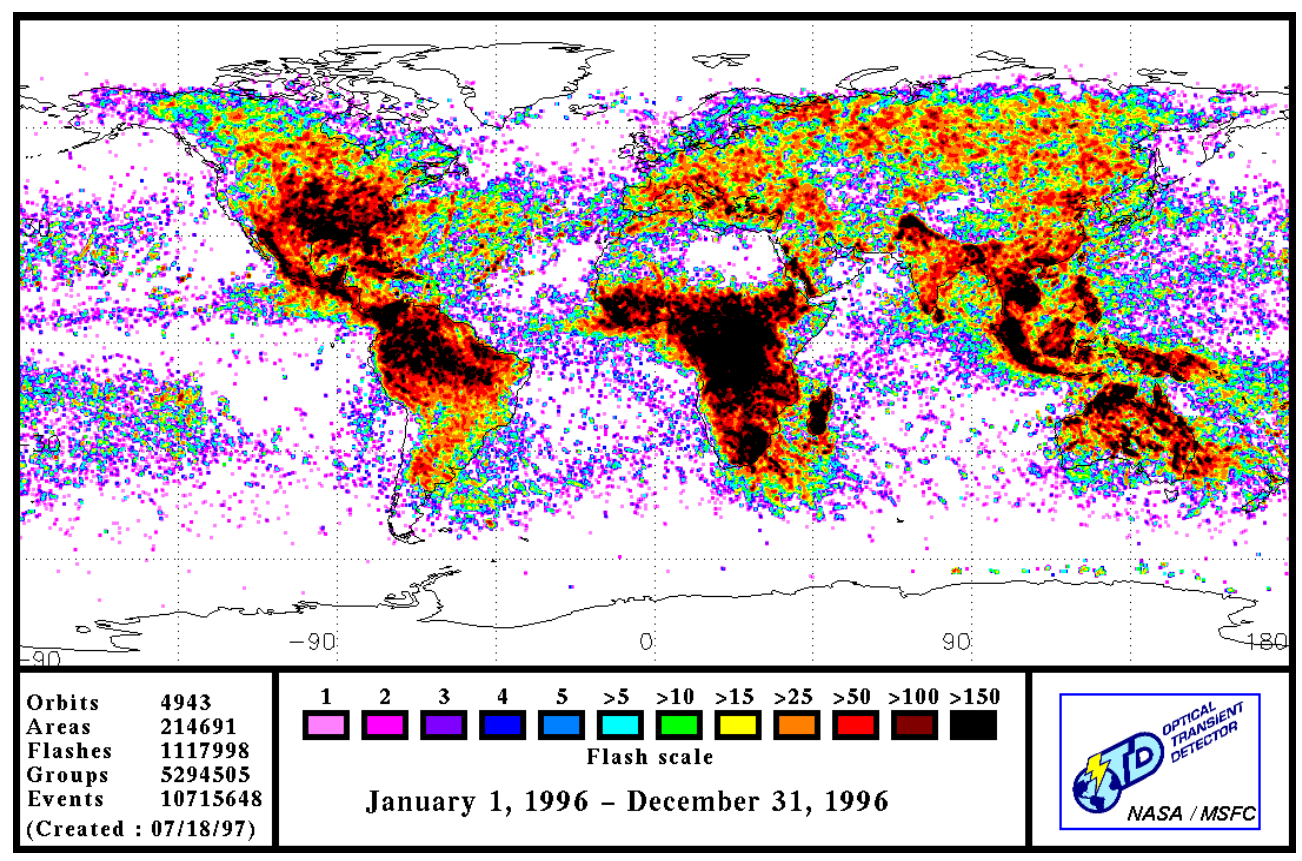

Figure 14. Source: http://www.tau.ac.il.

Naturally there do occur more thunderstorms at the northern hemisphere than the southern hemisphere, because there is more land and also variation in geomorphology.

There is also a tendency of a sequence increase and condensing in time of tornado's in the United States, Europe, China and Japan, while these intervals and condensing effect cannot be noted from the southern hemisphere. Evidence of a sequence increase and condensing effect of tornados can be noted if you face the list of tornadoes striking downtown areas of large cities [58]. The buoyancies in the temperate northern hemisphere cell seems to be very related to the increase in number and consecutive densities over the last decades due to an increase of nano structured particles in the higher troposphere and lower stratosphere.

Next to this conclusive remark there is evidence that nano structured particles move at the level of the higher troposphere and lower stratosphere from the temperate northern hemisphere cell to the Arctic cell. Evidence can be found in a unique catastrophic nuclear accident of Chernobyl on April, 26, 1986 in the Ukraine. Large quantities of traceable radioactive 134-Cesium and 137-Cesium particles were put in the atmosphere and spread over western Russia and Europe, as can be seen in Figure 15. Most of these unique 134-Cesium and 137-Cesium nano sized particles got in the higher troposphere and lower stratosphere and moved over Europe and to the Arctic, crossing the Arctic jet stream. The tendency to the north was not only initiated by wind direction, but also to the charging of the particles and was driven on the magnetic field towards the North Pole (Figure 15).

A second unique catastrophic disaster was the Daiichi nuclear power plant of Fukushima, Japan, sending the same traceable 134-Cesium and 137-Cesium nano structured particles into the troposphere up to the stratosphere. The fall out spread could only be observed in the northern temperate climate cell and the Arctic climate cell and didn't cross or even mixed with the tropical Hadley cell. This proves evidence that particles and nano sized particles produced at the northern hemisphere do not cross the tropical Hadley cells and influence the southern hemisphere (Figure 16). These 134-Cesium and 137-Cesium nano sized particles are charged and do move along magnetic field lines towards the North Pole, as a result directly deposit majorly into the Arctic (Figure 16).

Both nuclear disasters give evidence that anthropogenic particles and nano structured particles remain in the northern temperate climate cell and if charged, they only spread towards the North Pole crossing the Arctic jet stream. Nearly all photographs of the Arctic taken show a haze at the horizon, because of stratospheric dispersed pollution as stated earlier in this article. Particle lifetime in the stratosphere is about 1 to 2 years, compared to less than two weeks in the lower troposphere [30]. 


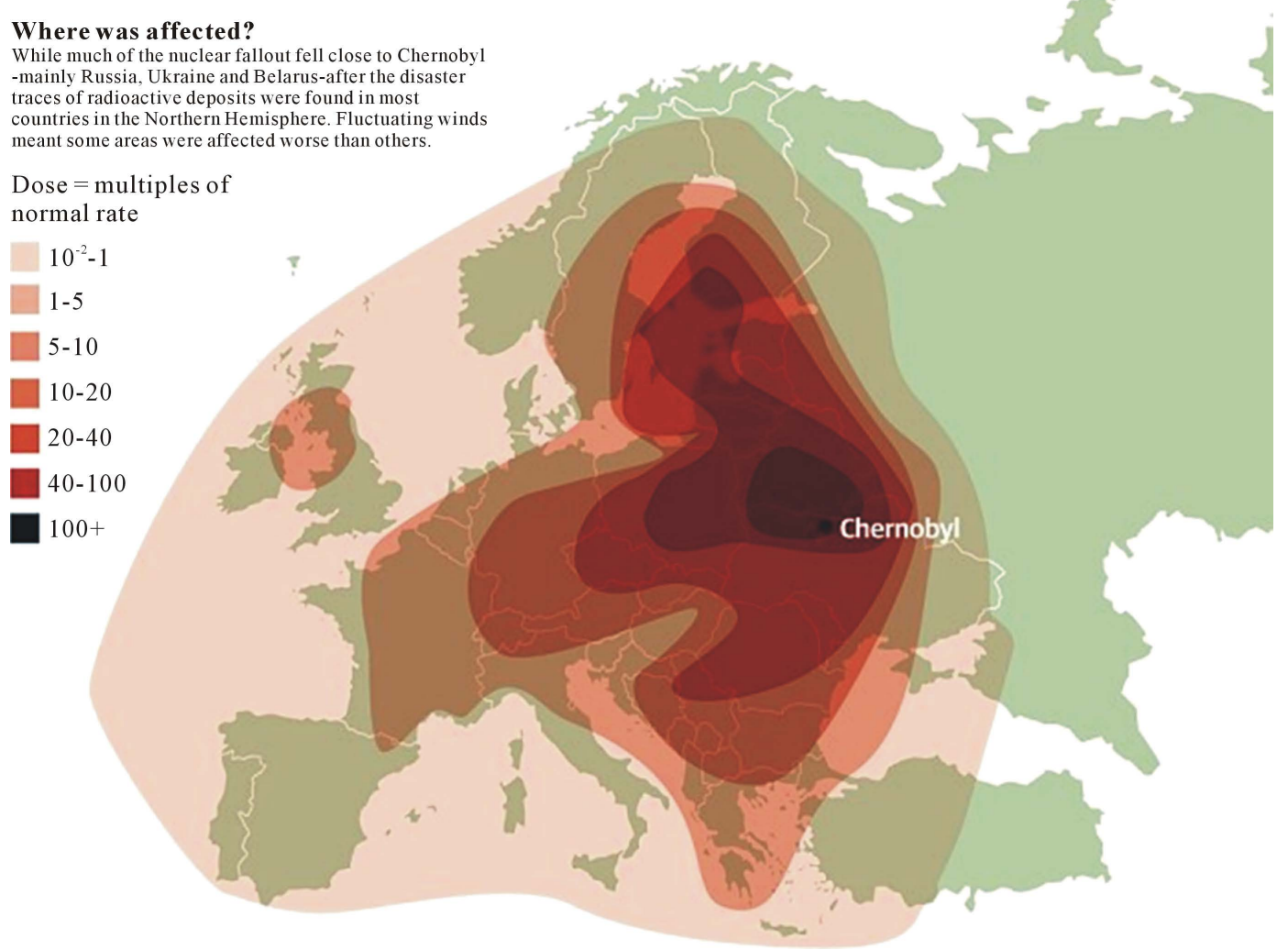

Figure 15. Source: http://www.dailymail.co.uk/sciencetech/article.

FUKUSHIMA Potential Release:

Xe-133, Total Column

Analysis: 2011-04-20 03:00:00, Date: 2011-04-30 06:00:00 UTC

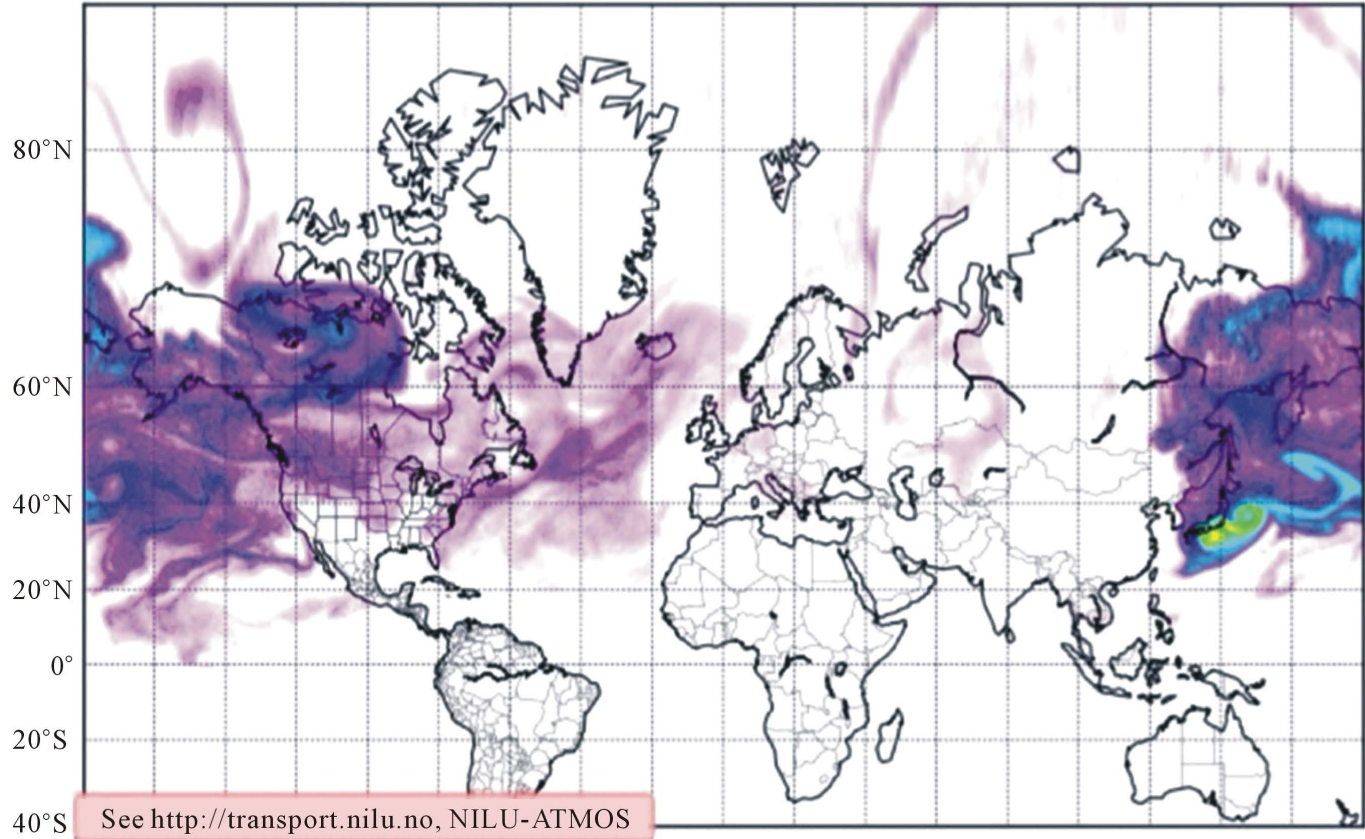

$\mathrm{Bq} / \mathrm{m}-2$

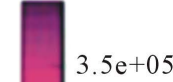

$1.1 \mathrm{e}+05$

$3.4 \mathrm{e}+04$

$1.1 \mathrm{e}+04$

$3.4 \mathrm{e}+03$

$1 \mathrm{e}+03$

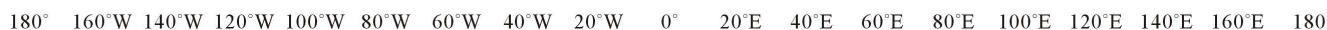

Figure 16. Source: http://www.globalresearch.ca. 


\section{Earth Feed-Back Systems to Climate Shifts in the Climate Cells}

The best global atmospheric feed-back system to climate shifts in a climate cell is naturally a cumulonimbus cloud formation in the atmosphere and the cooling effect during thunderstorms, as discussed earlier.

A second important feed-back system is hidden in the oceans. The ocean circulation moderates the climate effects across the climate cells, because they are enforced by wind and Coreolis force in a very slow-motion driven pattern and thus cross the climate belts, as depicted in Figure 17.

At both hemispheres are the surface currents interacting with the atmosphere. At the Arctic, a relative less saline surface current exchange heat to the atmosphere in the Arctic Sea, and provides a reverse relative high saline deep current in the Atlantic Ocean.

Opposite to the Arctic is the Antarctic dominated by a strong circumference circular current. The Antarctic current has a high saline cold undercurrent, based on Antarctic bottom water and circumpolar deep water upwelling that mixes with deep saline cold water of the North Atlantic Ocean, the very cold saline and more voluminous Pacific Ocean and the relative smaller input of cold saline Indian Ocean. At the surface occurs a mixture of relative low saline sub Antarctic mode of oscillating water and Antarctic intermediate water, both nourished by a complex of partly circular warmer water currents of the Atlantic Ocean, Indian Ocean and Pacific Ocean (Figure 18).

This influences greatly the melting pattern of Antarctic glaciers in the southern ocean. The complex system of mixed relative low saline warmer surface water is the most important factor of the melting of the Amundsen and Bellingshausen thinning sea ice and causes a more homeostatic situation at the other coastal areas of Antarctica. This is very much in contrast to the increasing ice accumulation on the Antarctica continent as explained in this article.

Opposite to the Antarctic is the Arctic suffering of great ice loss and ever thinner breaking and drifting off of ice shelves. The regulation by ocean currents is very different in compare to Antarctica. In the Artic Sea, a strong and predominant warm and relative low saline current of the North Atlantic Current get trapped, completely surrounded by continents (Figure 19). The heat exchange to the Arctic atmosphere can only take place by a series of warm circular currents in the Arctic Sea. Because of the warming of the temperate climate cell and the fact that negative charged nano sized particles have a tendency to move to the North Pole, heat exchange between the temperate northern climate cell and the Arctic polar cell increases. The Arctic atmosphere gets warmer, especially in the lower troposphere, resulting in a less quantitative heat exchange, while the warm North Atlantic Current continues to transport warm surface water. This results in a rapid ice loss and an increasing depletion until a new homeostatic situation is established according to the average new balance between the atmospheric temperature and the cooling capacity concerning the North Atlantic Current.

This is evidently in line with the sea ice anomaly finding of NASA (2013) over the period 1979 till 2012 and remains still uncertain to the extent of sea ice depletion in the Arctic, as depicted in Figure 20.

In contrast to the North Pole, the anomaly of sea ice in Antarctica doesn't change so much over the years 1979 till 2012 and is evidently homeostatic (Figure 21). Both figures on sea ice anomalies are also in accordance to all the findings in this article.

Thermohaline Circulation

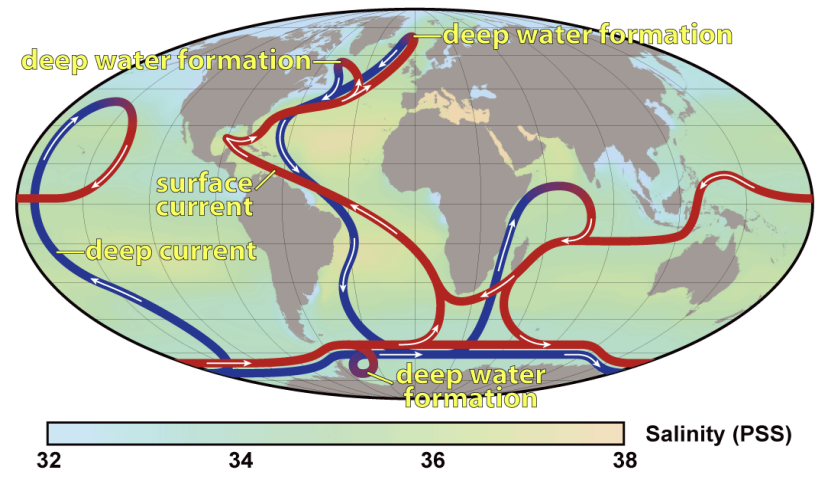

Figure 17. Source: Robert Simmon, minor modifications by Robert A. Rhode, NASA Earth Observatory. 


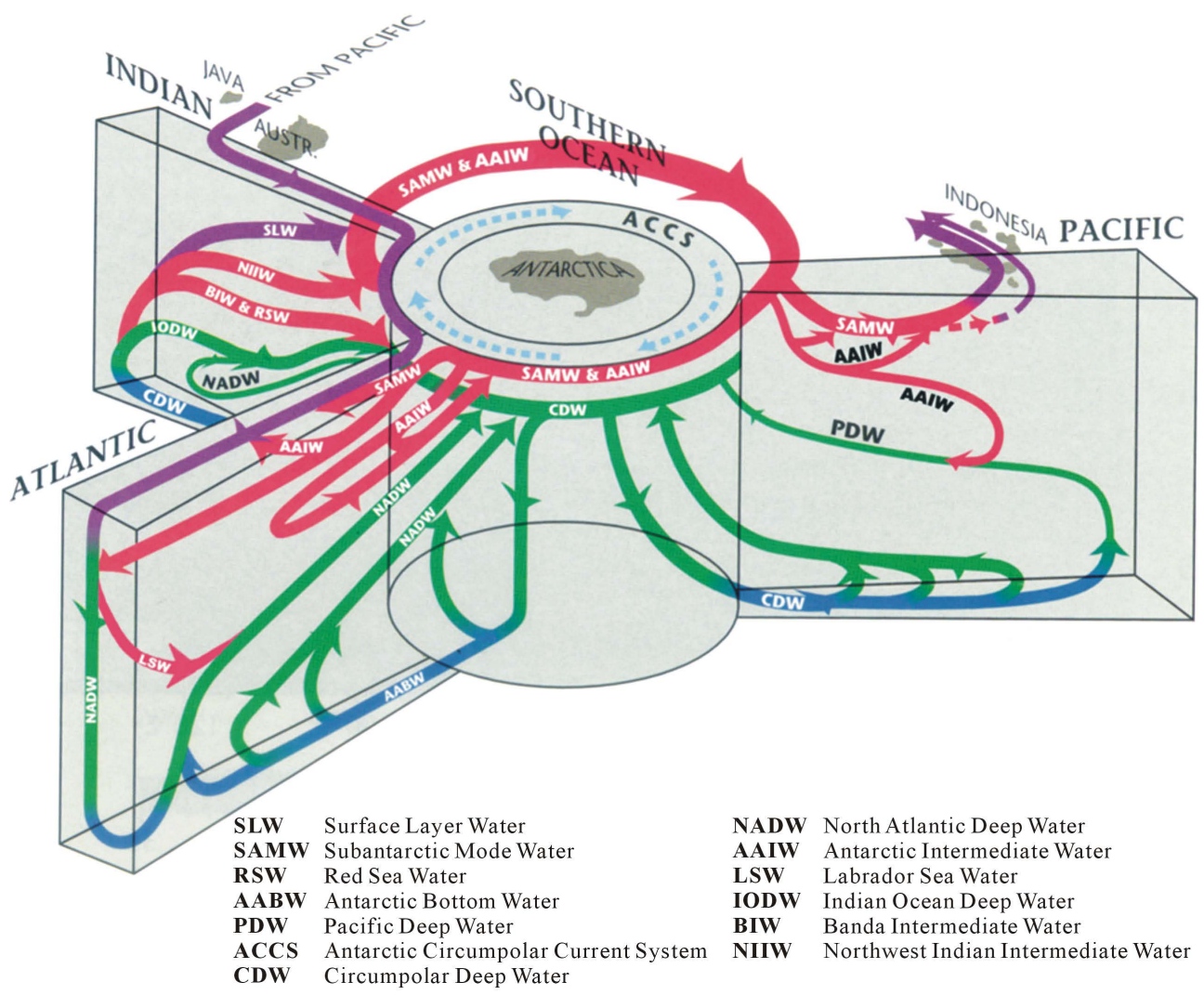

Figure 18. Source: From Siedler, 2001, figure 1.2.7, as taken from Schmitz, 1996.

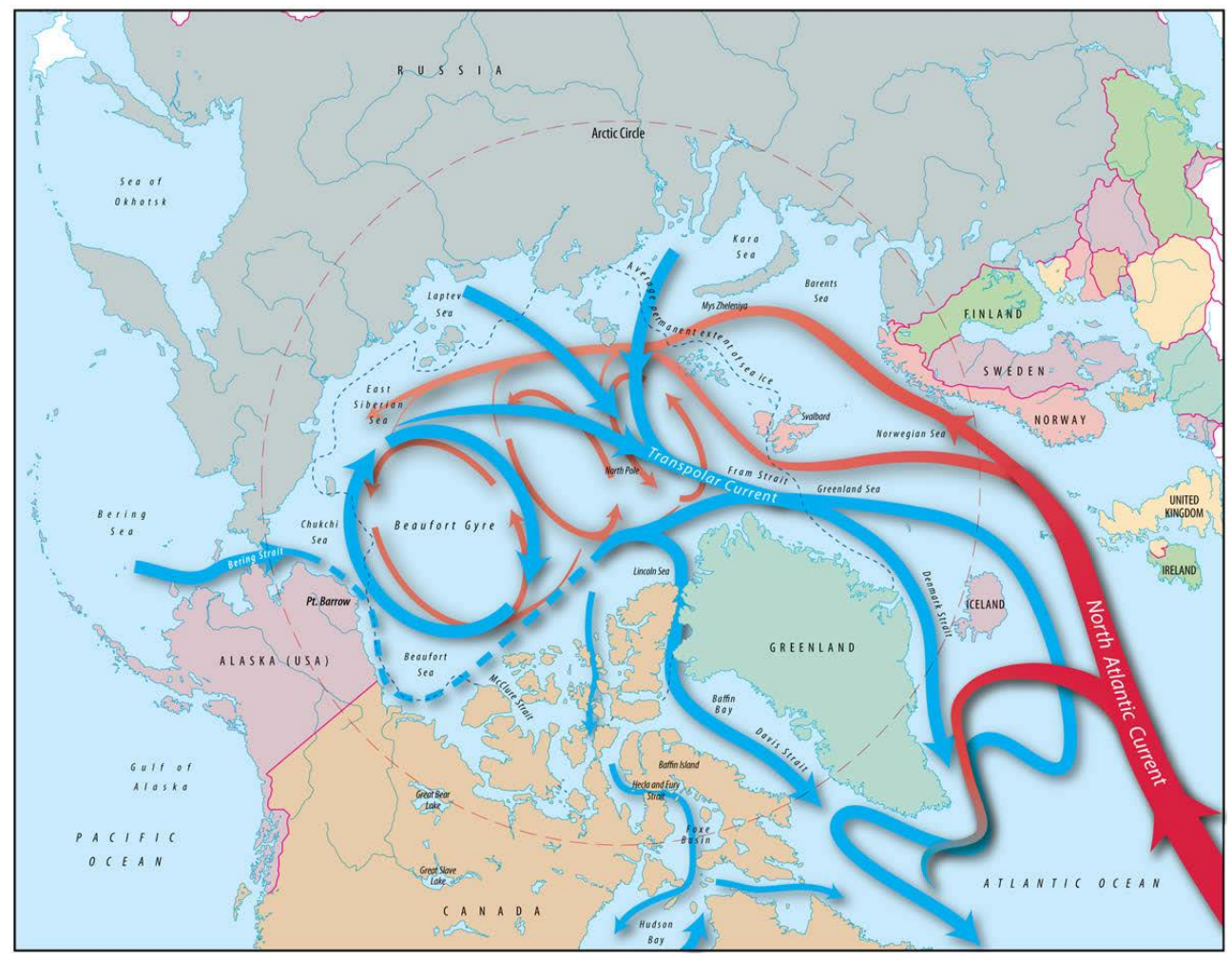

Figure 19. Source: Jack Cook, Woods Hole Oceanographic Institute. 


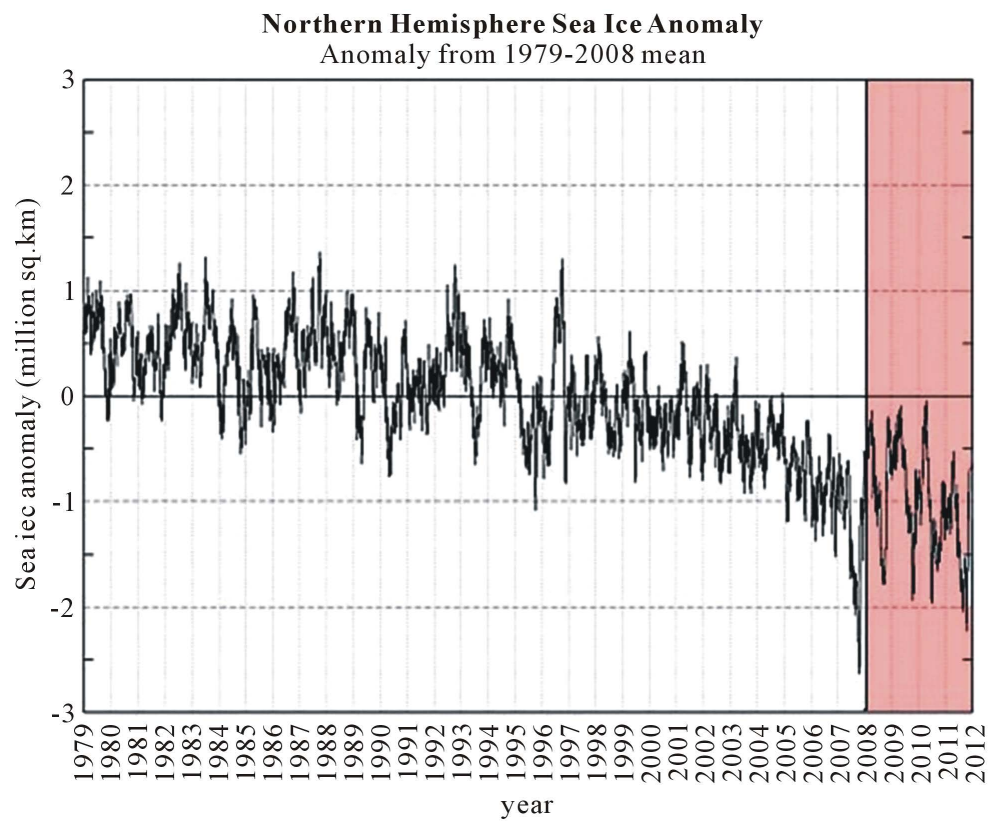

Figure 20. Source: http://www.climateaudit.org.

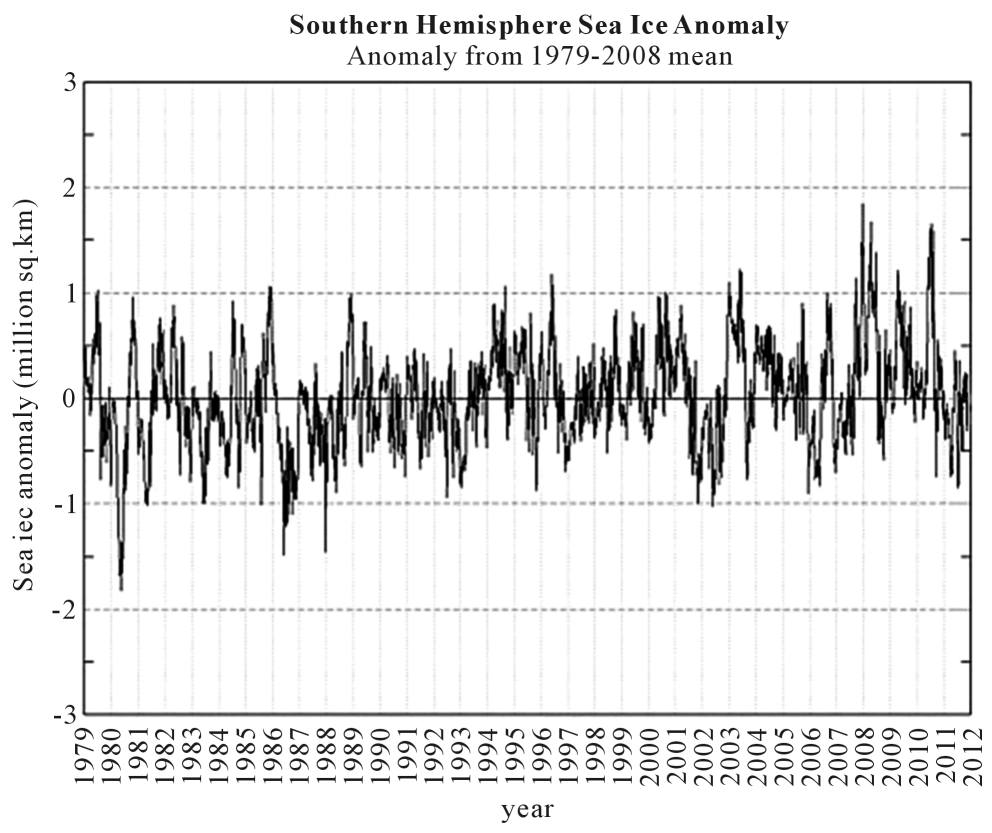

Figure 21. Source: http://www.climateaudit.org.

The third natural feedback system to climate shifts is vegetation. Plants transpire and contribute to cooling and regulation of climate extremes. In the tropics is vegetation the major driver of a homeostatic climate. This is very much in contrast to the poles, where vegetation only consists of low growing herbs and shrubs. But in the subarctic tundra and the Arctic boreal belt an increase of structural vegetation and plant roughness can be observed because of climate shifts. This is in coherence with vegetation adaptation on a tundra to carbon dioxide fixation [52]. Plant naturally response on changes of environmental impact and contribute to balance to climate shifts. Assisted migration of vulnerable species for nature conservation and to enhance the response to climate adaptation is needed. 


\section{Manmade Feed-Back Systems to Climate Shifts in the Climate Cells}

There are possible and feasible solutions to climate shifts, although people think different wise and remain keeping records of changes in climate readings and monitoring climate variations and impacts. If we reduce the emission of carbon dioxide, we could still ignore the fact of nano structured emissions or we had to shut down all our combustion systems and try to live without its existence. This is unthinkable in our present world. So we have to use a technological approach next to the ultimate reduction of our emissions to the atmosphere, especially on the northern hemisphere that is populated by 90 percent of mankind. We can assist in migrating wild species, vulnerable or useful, to reduce earth given life forms and hope for the best to avoid to a stage of limiting our own life quality and environment.

But we can also use all efforts, reduction of energy consumption, life wise living with respect of our environment, and apply technology to mitigate the climate shift to less extremes, and proportions that earth can regulate it again according to natural pathways and systems. This can be done the best to diminish the emission of nano structured particles of anthropogenic combustion processes into our atmosphere with a largely implementation of the ultra-fine dust reduction system (UFDR-System), as developed and designed by the author, on every suitable applied edifice or simple along dense traffic systems in urban areas. The principle of the UFDRSystem is based on natures concept and uses high positive Voltage to charge particles of 10 nano in diameter or larger uniformly and capture (charged, sent, directed and fixed) these on a grounded conductive surface and thus remove all nano structured and larger particulate matter before it is exhausted into the air. A reduction of nano sized particle emission will have an impact that last only for a period of two years or a little bit longer due to extension of the lifespan of a particle in the stratosphere [30] and will result a major contribution to our climate shift problem with all extremes, pollution and impact on our and natures environment. With an efficiency of at least a reduction of $60 \%$ in open air applied systems on all particulates of 10 nano or larger in any urban area provides a major contribution so that nature's solutions can take over and re-balance our atmosphere.

\section{Final Remarks and Conclusion}

What started as a hypothesis of the postulation of climate shift and the role of nano structured particles in the atmosphere, became an in depth study of the whole climate on the globe and all possible interactions in the troposphere, stratosphere and feed-back systems, such as cumulonimbus, especially in the tropics, include tipping the essence of the complex cooling systems of the ocean currents. It is clear that we cannot talk about a generic global warming, because the northern hemisphere differs greatly in climate response in compare to the southern hemisphere. Furthermore, hard evidence is given in this article and stated by other references (i.e. Kroonenberg, Miskolszi, Sistla and many more), which we do not change our global climate towards a warmer climate and eventually will result in an atmosphere depletion.

Mankind faces climate shifts in atmospheric independent climate cells and that does affect the northern temperate hemisphere cell the most and with an additional strong impact in the Arctic. Earth provides also, perpendicular to this northern and Arctic climate cell warming, a relative cooling due to net ice accumulation at the southern hemisphere and an increase in cumulonimbus clouds reaching far into the stratosphere in the tropics. These latter important drivers of our global cooling in contrast to warming will balance the global climate greatly, and so do vegetation with an increase of stomata and increasing vegetation shifts to larger sized plants with a possible larger leaf surface ratio (LAR) or a dense leaf setting (LAI) as presented in this article. Carbon dioxide is not the trigger of a global climate change, nor a climate shift, but a very important indicator for the amount of particulate matter and particular nano structured particle anthropogenic emissions into the troposphere that passes the threshold of the boundary layer into the stratosphere to coagulate and nucleate with the $20 \%$ water vapour content into droplets and ice. These nano structured based droplets and ice capture the upwardly directed long-wave radiation, inducing a climate shift in the temperate climate cell. Blue jets, huge smoke plumes, lightning, photophoretic and electrical forces do move nano sized particles upwards into the higher troposphere and lower stratosphere onto a more extreme and violent buoyancy of the atmosphere and a permanent visible haze in the northern temperate climate cell and the Arctic.

A reduction of nano sized particle emission, indicated by the carbon dioxide footprint, will give an effect in a period of two years or a little bit longer due to dragging the lifespan of a particle in the stratosphere [30] and will result in less turbulent and exceptional climate effects in the temperate and Arctic climate cell. Nano sized parti- 
cle reduction can be achieved with the fine dust reduction system device that is created by the author in 2001 and proves its effect in open air (at least a 60 percent reduction of particles with 10 nano metres diameter or more) and indoors (99.99 percent reduction on nano structured particles or larger diameters). The atmosphere recuperates to an extent before the domination of anthropogenic pollution in the troposphere and stratosphere with these extremes.

However, the effect of these climate shifts in the temperate climate cell and the Arctic cell as discussed in this article, has and will have an enormous impact on nature that could not response in a fast enough evolutionary adaptation and will give a great loss of biodiversity, resulting in the highest depletion rate since the end of the era of the Palaeozoic, 250 million years ago. These climate shifts also affects mankind that will be confronted and should deal with recycled pollution of particulate matter and nano structures affecting health and life quality.

Next to this, a global net mediated sea level rise of an estimated 0.59 meter is predicted according to the IPCC records (IPCC, 2007 and still in the 2014 report again stated). The IPCC global sea level rise estimation is factual based on $70 \%$ expansion, due to lacking of heat exchange of ocean currents to the atmosphere, and on $30 \%$ estimated contribution of glacier melting on land. This figure needs to be put in prospective according to evidence in the past and others as discussed in this article.

In the past drastic variation of sea level rise had occurred. The most striking is the 60 - 80 meters worldwide sea level drop at about 34 million years ago, when Antarctica changes in a short period from a temperate into a polar climate [59]. Stocchi et al. combined several geophysical models and proofs that the shelf around East Antarctica first shoaled due to an Earth mantle material upwelling, then resulting in a rounded swelling which distorts development to form a mass that attracted masses of water, resulting in an increase of a sudden 150 meter sea level rise around Antarctica and shifts the Antarctic climate until now known as a polar one.

At the present we have also huge differences in sea levels in the oceans, due to currents and temperature variation, so an average of sea level rise of approximately $0.59 \mathrm{~m}$ in the future is very difficult to give in this respect, and if so, it will fall in the fault margins of data all around the globe. The impact of 34 million years ago didn't change in a temperature difference at a global scale; it was a dramatic change in the Arctic climate cell with an impact on the temperate southern cell.

So, if we put the present climate shift in prospective, we do have to concentrate on the emissions of particulate matter and with a focus on the nano structured particles. But we can halter the effect of climate shifts by reducing the particulate matter and especially the nano structured particles in the northern temperate and Arctic climate belt and we can use carbon dioxide reduction as a useful footprint and indicator. Like solving the acid rain problem and ozone depletion in the past, we can equally recuperate our climate if we reduce air borne nano structured particles that results in a recorded impact in a period of two years or a little bit longer due to extension of the lifespan of a particle in the stratosphere [30]. A positive prospective in a very buoyancy and increasing extreme climate future otherwise.

Notes:

1) Next to this, is the speculation of the IPCC that we face a $4 \mathrm{Watt} / \mathrm{m}^{2}$ extra heat flow, because of the expected double $\mathrm{CO}_{2}$ emission, and that this will lead to a global three degrees Celsius temperature increase.

2) Cristobalite particles of the eruption of Chaitén Volcano with a length of a few hundred nanometres and a width of 20 till 50 nanometre. It is believed that cristobalite nano fibres are formed during explosive eruptions at a temperature of more than $240^{\circ} \mathrm{C}$ while amorphous silica is reduced by carbon monoxide to a reactive sub-oxide $\mathrm{SiO}_{2}$ that in a later phase oxidized till one-dimensional crystalline silica nanostructures in the air. Due to nucleation and growth of the nano fibres, it enhanced the surface area to form nanometre-sized fragments of silica glass in the air and also as deposit in a volcanic column [60].

3) Sub-micron bacteria are harvested, after washing with a phosphate buffer and a 0.2 micrometre cellulose nitrate filter, and detected as cocci-bacteria.

4) A subsonic aircraft flies in the upper troposphere at an altitude about 9 to $13 \mathrm{~km}$, while supersonic aircrafts cruise at about 17 to $20 \mathrm{~km}$ altitude and thus flying in the stratosphere.

5) The photophoretic force should be positive in order to form an upward directed momentum. It is known that particles of burning processes can create a negative momentum such as in the case of smoke production captured in a small convergent laser beam due to dielectric electromagnetic interaction in a non-buoyancy-driven air flow and in micro-gravity conditions that results in a direct electromagnetically interaction near the focal point and a clearly subjection to a photophoretic force far from the focal point. 


\section{References}

[1] Stocker, T.F., Qin, D., Plattner, G.K., Trignor, M.M.B., Allen, S.K., Boschung, J., Naeles, A., Xia, Y., Bex, V. and Midgley, P.M. (2013) Climate Change 2013: The Physical Science Basis. Fifth Assessment Report, Intergovernmental Panel on Climate Change (IPCC). Cambridge University Press, Cambridge.

[2] Miskolszi, F.M. (2007) The Greenhouse Effect in Semi-Transparent Planetary Atmosphere. Quarterly Journal of the Hungarian Meteorological Service, 111, 1-40.

[3] Garret, J.R. (1992) The Atmospheric Boundary Layer. Cambridge University Press, Cambridge.

[4] Barnard, A.S. and Guo, H. (2012) Nature’s Nanostructures. Pan Stanford Publishing Pte. Ltd., Singapore.

[5] Engelbrecht, J.P. and Derbyshire, E. (2010) Airborne Mineral Dust. Elements, 6, 241-246. http://dx.doi.org/10.2113/gselements.6.4.241

[6] Wainwright, M., Wickramasinghe, N.C., Narliakar, J.V. and Rajaratnem, P. (2003) Microorganisms Cultured from Stratospheric Air Samples Obtained at 41 km. FEMS Microbiology Letters, 218, 161-165. http://dx.doi.org/10.1111/j.1574-6968.2003.tb11513.x

[7] Thomas-Keptra, K.L., Clemett, S.J., Bazylinski, A., Kirschvink, J.L., McKay, D.S., Wentworth, S.J., Vali, H., Gibson, E.K. and Romanek, C.S. (2002) Magnetofossils from Ancient Mars: A Robust Biosignature in the Martian Meteorite ALH84001. Journal of Applied and Environmental Microbiology, 68, 3663-3672. http://dx.doi.org/10.1128/AEM.68.8.3663-3672.2002

[8] Wainwright, M., Wickramasinghe, N.C., Narlikar, J.V. and Rajaratnam, P. (2004) Are These Stratospheric Nanoparticles Bacteria? Microbiology, 150, 756-758. http://dx.doi.org/10.1099/mic.0.26907-0

[9] Bigg, E.K. (1984) Particles in the Upper Atmosphere. Fundamental Studies and the Future of Science. University College Cardiff Press, Cardiff, 38-51.

[10] Harris, M.J. et al. (2002)The Detection of Living Cells in the Stratosphere. Proceedings SPIE Conference Instruments, Methods, and Missions for Astrobiology IV, San Diego, 2002, 192-198.

[11] Griffin, D.W. (2004) Terrestrial Microorganisms at an Altitude of 20000 m in Earth’s Atmosphere. Aerobiologia, 20, 135-140. http://dx.doi.org/10.1023/B:AERO.0000032948.84077.12

[12] Mariq, M. (2010) Characterization of Combustion and Engine Exhaust Particles. In: Marijnisen, J. and Gradoń, L., Eds., Nanoparticles in Medicine and Environment, Springer Press, Dordrecht, 19-37. http://dx.doi.org/10.1007/978-90-481-2632-3_2

[13] Herndon, S.C., Onasch, T.B., Frank, B.P., Marr, L.C., Jayne, J.T., Canagaratna, M.R., Grygas, J., Lanni, T., Anderson, B.E., Worsnop, D. and Miake-Lye, R.C. (2005) Particulate Emissions from in-Use Commercial Aircraft. Aerosol Science and Technology, 39, 799-809. http://dx.doi.org/10.1080/02786820500247363

[14] Hopke, P.K. (1985) Receptor Modelling in Environmental Chemistry. John Wiley \& Sons, New York, 276-314.

[15] Pasko, V.P., Stanley, M.A., Mathews, J.D., Inan, U.S. and Wood, T.G. (2002) Electrical Discharge from Thundercloud Tops to the Lower Ionosphere. Nature, 416, 152-154. http://dx.doi.org/10.1038/416152a

[16] Rohatschek, H. (1996) Levitation of Stratospheric and Mesophillic Aerosols by Gravito-Photophoresis. Journal of Aerosol Sciences, 27, 467-475. http://dx.doi.org/10.1016/0021-8502(95)00556-0

[17] Rosenberg, M., Mendis, D.A. and Sheehan, D.P. (1999) Positively Charged Dust Crystals Induced by Radiative Heating. IEEE Transactions on Plasma Science, 27, 239-242. http://dx.doi.org/10.1109/27.763125

[18] Tehranian, S., Giovane, F., Blum, J., Xu, Y.-L. and Gustafson, B.A.S. (2001) Photophoresis of Micrometer-Sized Particles in the Free-Molecular Regime. International Journal of Heat and Mass Transfer, 44, 1649-1657. http://dx.doi.org/10.1016/S0017-9310(00)00230-1

[19] Welch, R. and Zdunkowski, W. (1976) A Radiation Model of the Polluted Atmospheric Boundary Layer. Journal of the Atmospheric Sciences, 33, 2170-2184. http://dx.doi.org/10.1175/1520-0469(1976)033<2170:ARMOTP>2.0.CO;2

[20] Zdunkowsky, W.G. and Korb, G. (1974) An Approximate Method for the Determination of Long Wave Radiative Fluxes in Scattering and Absorbing Media. Beitraege Physikalische Atmosphere, 47, 129-144.

[21] Rodgers, C.D. (1976) The Use of Emissivity in Atmospheric Calculations. Quarterly Journal of the Royal Meteorological Society, 93, 43-53. http://dx.doi.org/10.1002/qj.49709339504

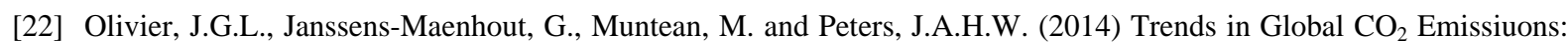
2014 Report. PBL Netherlands Environmental Assessment Agency, The Hague.

[23] Jackman, C.H. and McPeters, R.D. (2000) The Effect of Solar Proton Events on Ozone and Other Constituents, NASA Technical Documents. John Wiley \& Sons, New York, 1-27.

[24] Clay, J. (1951) Atmosferische Electriciteit. Servire, The Hague, 48-51.

[25] Becquerel, A.C. (1847) Eléments de physique terrestre et de météorologié. Frimin Didot, Paris. 
[26] Svensmark, H., Pendersen, J.O.P., Marsh, N.D. and Uggerhøy, U.I. (2007) Experimental Evidence for the Role of Ions in Particle Nucleation under Atmospheric Conditions. Proceedings of the Royal Society A, 463, 385-396.

[27] Miskolszi, F.M. (2004) The Greenhouse Effect and the Special Decomposition of the Clear-Sky Terrestrial Radiation. Quarterly Journal of the Hungarian Meteorological Service, 108, 209-251.

[28] Gerrits, A.M.J. (2010) The Role of Interception in the Hydrological Cycle. Ph.D. Dissertation, Delft University of Technology, Delft.

[29] Petersen, W.A., Nesbitt, S.W., Blakeslee, R.J., Cifelli, R., Hein, P. and Rutledge, S.A. (2002) TRIMM (Tropical Rainfall Measuring Mission) Observations of Intraseasonal Variability in Convective Regimes over the Amazon. Journal of Climate, 15, 1278-1294. http://dx.doi.org/10.1175/1520-0442(2002)015<1278:TOOIVI>2.0.CO;2

[30] Hinds, W.C. (1999) Aerosol Technology, Properties, Behaviour, and Measurements of Airborne Particles. John Wiley \& Sons, New York.

[31] Yli-Juuti, T., Nieminen, T., Hirsikko, A., Aalto, P.P., Hŏrrak, U., Manninen, H.E., Patokoski, J., Dal Maso, M., Petäjä, T., Rinne, J., Kulmala, M. and Riipinen, I. (2011) Growth Rates of Nucleation Mode Particles in Hyytiälä during 20032009: Variation with Particle Size, Season, Data Analysis Method and Ambient Conditions. Atmospheric Chemistry and Physics, 11, 12865-12886. http://dx.doi.org/10.5194/acp-11-12865-2011

[32] Broomwich, D.H. and Guo, Z. (2004) Modelled Antarctic Precipitation Part 1: Spatial and Temporal Variability. Journal of Climate, 17, 427-447. http://dx.doi.org/10.1175/1520-0442(2004)017<0427:MAPPIS>2.0.CO;2

[33] Knuth, S.L. (2007) Estimation of Snow Accumulation in Antarctica Using Automated Acoustic Depth Gauge Measurements. M.Sc. Thesis, University of Wisconsin-Madison, Madison.

[34] Davis, C.H., Li, Y.H., McConnell, J.R., Frey, M.M. and Hanna, E. (2005) Snowfall-Driven Growth in East Antarctic Ice Mitigates Recent Sea-Level Rise. Science, 308, 1898-1901. http://dx.doi.org/10.1126/science.1110662

[35] Raper, S.C.B.T.M.L., Wigley, P.D., Jones, P.D., Kelly, P.M., Mayes, P.R. and Limbert, D.W.S. (1983) Recent Temperature Changes in the Arctic and Antarctic. Nature, 306, 458-459. http://dx.doi.org/10.1038/306458a0

[36] Jones, P.D., Raper, S.C.B. and Wigley, T.M.L. (1986) Southern Hemisphere Surface Air Temperature Variation: 1851-1984. Journal of Applied Meteorology and Climatology, 25, 1213-1230. http://dx.doi.org/10.1175/1520-0450(1986)025<1213:SHSATV >2.0.CO;2

[37] Usoskin, I.G., Solanki, S.K., Schüssler, M., Mursula, K. and Alanko, K. (2003) A Millennium Scale Sunspot Number Reconstruction: Evidence for an Unusually Active Sun Since the 1940's. Physical Review Letters, 91, Article ID: 211101.

[38] Hansen, J.E., Johnson, D., Lacis, A., Lebedeff, S., Lee, P., Rind, D. and Russell, G. (1981) Climate Impact of Increasing Atmospheric Carbon Dioxide. Science, 213, 957-966. http://dx.doi.org/10.1126/science.213.4511.957

[39] Purdie, H. (2011) Controls on Special and Temporal Variation in Snow Accumulation on Glaciers in the Southern Alps, New Zealand. Ph.D. Dissertation, School of Geography, Environment and Earth Sciences, Te Kura Tatāi Aro Whenua/ Victoria University of Wellington, Wellington.

[40] Solomon, S., Rosenlof, K., Portmann, R., Daniel, J., Saford, T. and Plattners, G.K. (2010) Contributions of Stratospheric Water Vapour to Decadel Changes in the Rate of Global Warming. Science, 327, 1219-1223. http://dx.doi.org/10.1126/science.1182488

[41] Rignot, E., Rivera, A. and Casassa, G. (2003) Contributions of the Patagonia Icefields of South America to Sea Level Rise. Science, 302, 434-437. http://dx.doi.org/10.1126/science.1087393

[42] De Jager, C. (1981) A Relation between Solar Activity and Winter Temperatures in Holland between 1634 and 1975. Proceedings of the Koninklijke Nederlandse Akademie van Wetenschappen. Series B, Physical Sciences, Amsterdam, 21 December 1981, 457-461.

[43] Svensmark, H. and Christensen, E.E. (1997) Variations of Cosmic Ray Flux and Global Cloud Coverage—A Missing Link in Solar-Climate Relationships. Journal of Atmospheric and Solar-Terrestrial Physics, 59, 1225-1232. http://dx.doi.org/10.1016/S1364-6826(97)00001-1

[44] Batten, M.L., Hu, C.P., Bacon, J.L. and Nelson, C. (1995) A Numerical Study of the Effects of Wind Forcing on the Chile Current System. Journal of Oceanography, 51, 585-614. http://dx.doi.org/10.1007/BF02270526

[45] Rivera, A. and Casassa, G. (1999) Volume Changes on Pio XI Glacier, Patagonia: 1975-1995. Global and Planetary Change, 22, 233-244. http://dx.doi.org/10.1016/S0921-8181(99)00040-5

[46] Stuefer, M. (1999) Investigations on Mass Balance and Dynamics of Moreno Glacier Based on Field Measurements and Satellite Imagery. Ph.D. Dissertation, University of Innsbruck, Innsbruck.

[47] Casassa, G., Rivera, A., Aniya, M. and Naruse, R. (2002) The Patagonian Icefields: A Unique Natural Laboratory for Environmental and Climate Change Studies. Springer US, New York, 67-83.

[48] Bowen, M. (2005) Thin Ice, Unlocking the Secrets of Climate in the World's Highest Mountains. Holt Paperbacks, 
New York, 327-396.

[49] Schumpf, M., Axmacher, J.C., Zech, W. and Lyaruu, H.V.M. (2011) Net Precipitation and Soil Water Dynamics in Clearings, Old Secondary and Old Growth Forests in the Montane Belt of Mount Kilimanjaro, Tanzania. Hydrological Processes, 25, 418-428. http://dx.doi.org/10.1002/hyp.7798

[50] Mölg, T., Cullen, N.J., Hardy, D.R., Winkler, M. and Kaser, G. (2009) Quantifying Climate Change in the Tropical Midtroposphere over East Africa from Glacier Shrinkage on Kilimanjaro. Journal of Climate, 22, 4162-4181. http://dx.doi.org/10.1175/2009JCLI2954.1

[51] Kroonenberg, S. (2008) De Menselijke Maat. Atlas Press, Amsterdam, 157-189.

[52] Sistla, S.A., Moore, J.C., Simpson, R.T., Gough, L., Shaver, G.R. and Schimel, J.P. (2013) Long-Term Warming Restructures Arctic Tundra without Changing Net Soil Carbon Storage. Nature, 497, 615-618. http://dx.doi.org/10.1038/nature12129

[53] Kittelson, D.B. (1998) Engines and Nanoparticles: A Review. Journal of Aerosol Sciences, 29, 575-588. http://dx.doi.org/10.1016/S0021-8502(97)10037-4

[54] Zhang, H., Hao, J., Wang, S., Wan, L., Jiang, J., Zhang, M., Mestl, H.E.S., Alnes, L.W.H., Aunan, K. and Mellouki, A.W. (2012) Chemical and Size Characterization of Particles Emitted from the Burning of Coal and Wood in Rural Households in Guizhou, China. Atmospheric Environment, 51, 94-99. http://dx.doi.org/10.1016/j.atmosenv.2012.01.042

[55] Price, C. (2009) Will Drier Climate Result in More Lightning? Atmosphere Research, 91, 479-484.

[56] Williams, E.R. (2005) Lightning and Climate: A Review. Atmospheric Research, 76, 272-287. http://dx.doi.org/10.1016/j.atmosres.2004.11.014

[57] Seeley, J.T. and Romps, D.M. (2015) The Effect of Global Warming on Severe Thunderstorms in the United States. Journal of Climate of the American Meteorological Society, 28, 2443-2458. http://dx.doi.org/10.1175/jcli-d-14-00382.1

[58] Wurman, J. (2015) Center for Severe Weather Research. Doppler on Wheels Data: Tornadoes 2000-2014

[59] Stocchi, P., Escutia, C., Houben, A.J.P., Vermeersen, B.L.A., Bijl, P.K., Brinkhuis, H., DeConto, R.M., Galeotti, S., Passchier, S., Pollard, D., Escutia, C., Klaus, A., Fehr, A., Williams, T., Bendle, J.A.P., Bohatv, S.M., Carr, A.A., Dunbar, R.B., Flores, J.A., Gonzàlez, J.J., Hayden, T.G., Iwai, M., Jimenez-Espeio, F.J., Katsuki, K., Kong, G.S., McKay, R.M., Nakai, M., Olney, M.P., Pekar, S.F., Pross, J., Riesselman, C., Röhl, U., Sakai, T., Shrivastava, P.K., Sticley, C.E., Sugisaki, S., Tauxe, L., Van de Flierdt, T., Welsh, K. and Yamane, M. (2013) Relative Sea-Level Rise around East Antarctica during Oligocene Glaciation. Nature Geoscience, 6, 380-384. http://dx.doi.org/10.1038/ngeo1783

[60] Reich, M., Zuniga, A., Amigo, A., Vargas, G., Morata, D., Palacios, C., Parada, M.A. and Garreaud, R.D. (2009) Formation of Cristobalite Nanofibers during Explosive Volcanic Eruptions. Geology, 37, 435-438.

http://dx.doi.org/10.1130/G25457A.1 